\title{
Fatty Acids and Membrane Lipidomics in Oncology: A Cross-Road of Nutritional, Signaling and Metabolic Pathways
}

\author{
Carla Ferreri ${ }^{1, *(1)}$, Anna Sansone ${ }^{1}\left(\mathbb{D}\right.$, Rosaria Ferreri ${ }^{2}$, Javier Amézaga ${ }^{3}\left(\mathbb{C}\right.$ and Itziar Tueros ${ }^{3} \mathbb{C}$ \\ 1 Istituto per la Sintesi Organica e la Fotoreattività, Consiglio Nazionale delle Ricerche, Via Piero Gobetti 101, \\ 40129 Bologna, Italy; anna.sansone@isof.cnr.it \\ 2 Department of Integrated Medicine, Tuscany Reference Centre for Integrated Medicine in the hospital \\ pathway, Pitigliano Hospital, Via Nicola Ciacci, 340, 58017 Pitigliano, Italy; rosariaferreri1957@gmail.com \\ 3 AZTI, Food and Health, Parque Tecnológico de Bizkaia, Astondo Bidea, Edificio 609, 48160 Derio, Spain; \\ jamezaga@azti.es (J.A.); itueros@azti.es (I.T.) \\ * Correspondence: carla.ferreri@isof.cnr.it
}

Received: 1 August 2020; Accepted: 23 August 2020; Published: 25 August 2020

check for updates

\begin{abstract}
Fatty acids are closely involved in lipid synthesis and metabolism in cancer. Their amount and composition are dependent on dietary supply and tumor microenviroment. Research in this subject highlighted the crucial event of membrane formation, which is regulated by the fatty acids' molecular properties. The growing understanding of the pathways that create the fatty acid pool needed for cell replication is the result of lipidomics studies, also envisaging novel fatty acid biosynthesis and fatty acid-mediated signaling. Fatty acid-driven mechanisms and biological effects in cancer onset, growth and metastasis have been elucidated, recognizing the importance of polyunsaturated molecules and the balance between omega- 6 and omega- 3 families. Saturated and monounsaturated fatty acids are biomarkers in several types of cancer, and their characterization in cell membranes and exosomes is under development for diagnostic purposes. Desaturase enzymatic activity with unprecedented de novo polyunsaturated fatty acid (PUFA) synthesis is considered the recent breakthrough in this scenario. Together with the link between obesity and cancer, fatty acids open interesting perspectives for biomarker discovery and nutritional strategies to control cancer, also in combination with therapies. All these subjects are described using an integrated approach taking into account biochemical, biological and analytical aspects, delineating innovations in cancer prevention, diagnostics and treatments.
\end{abstract}

Keywords: cancer cell membranes; fatty acid biosynthesis; essential fatty acids; desaturase enzymes; fatty acid signaling; fatty acid biomarker; sapienic acid; sebaleic acid; molecular nutrition; inflammation

\section{Introduction}

The development of lipid research in the last two decades has brought a fundamental contribution to the understanding of the main processes for cellular life, in all types of organisms as well as in plants [1]. In particular, fatty acids are the building blocks of the large majority of lipid structures, differentiated from lipids that have steroid and isoprenoid scaffolds. Fatty acids are known for their multiple roles, ranging from energy providers and gene regulators to precursors of signaling molecules and other important metabolites, but it is worth noting that fatty acids in phospholipids have specific structural and functional roles in order to create the envelope of all types of cells, i.e., the cell membrane [2]. In eukaryotes, fatty acids display structural diversity and, as represented in Figure 1 with the most important molecules for the organization of membrane phospholipids, are characterized 
by specific chain length and number of unsaturations. First of all, the length of the hydrocarbon (hydrophobic) chains requires a certain number of carbon atoms (most often 16-22 carbon atoms) to create the membrane compartment and the thickness of the lipid bilayers. Biosynthesis is initiated with the formation of 16 carbon atoms containing palmitic acid, the first endogenous lipid which is a saturated fatty acid (SFA) (Figure 1) made by the enzymatic system of fatty acid synthase (FAS). Together with the chain length, another structural requirement present in unsaturated fatty acids is the geometry of cis double bonds. The enzymatic system of desaturases introduces the unsaturation in a precise position of the fatty chain (indicated with the carbon atom number; see Figure 1) and this creates a bend (angle of ca. 30 degrees), modifying profoundly the biophysical properties of the molecules [3]. The main endogenous formation of double bonds is due to delta- $9(\Delta 9)$ desaturase (also known as stearoyl CoA desaturase SCD-1) operating on palmitic and stearic acids, as shown in Figure 2A.

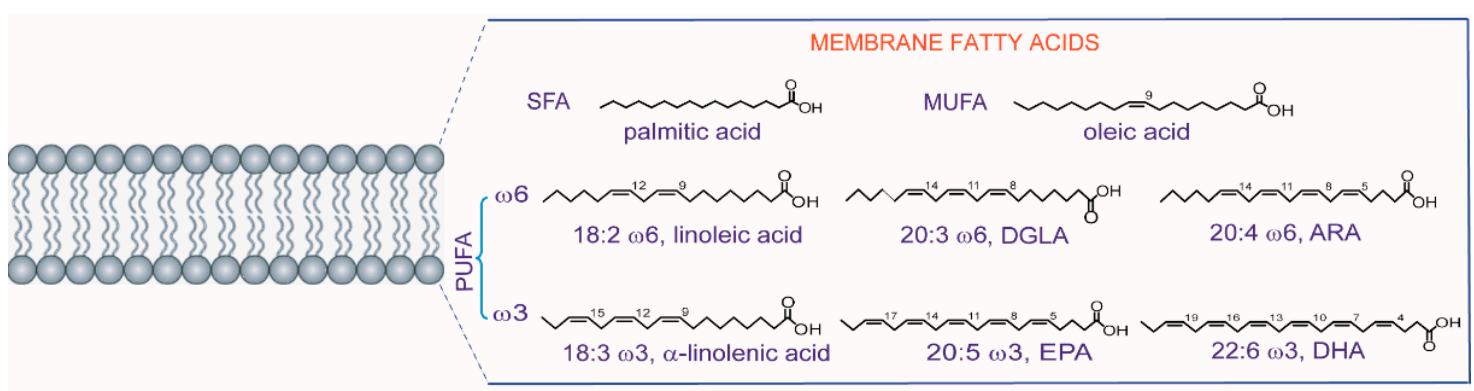

Figure 1. The fatty acid constituents of phospholipids: saturated fatty acids (SFA), monounsaturated fatty acids (MUFA) and polyunsaturated fatty acids (PUFA) are shown with their most present structures in eukaryotic membranes.

On the other hand, the polyunsaturated fatty acid (PUFA) structures are necessary to eukaryotic cells but are not biosynthesized de novo, and the precursors of the omega- 6 and omega- 3 families must be taken from the diet. The structures of the omega- 6 and omega-3 precursors are shown in Figure 1 (linoleic acid and $\alpha$-linolenic acid, respectively) and, after their uptake, other PUFAs are formed and enter into the membrane composition, as shown in Figure 1. In Figure 2B, the two pathways followed for long-chain PUFA biosynthesis are shown, with formation of omega-6 di-homo-gamma linolenic (DGLA) and arachidonic (ARA) acids and omega-3 eicosapentaenoic (EPA) and docosahexaenoic (DHA) acids. As a matter of fact, the transformation to mono- and polyunsaturated fatty acids (MUFA and PUFA) provides the precious building blocks of membrane phospholipids involved in the regulation of permeability and fluidity properties. MUFAs and PUFAs act in a manner opposite to SFA, which instead create the rigidity and the gel status of the lipid bilayer. The role of fats in cancer is generally recognized [4], and the SFA-MUFA pathway has been studied since it is one of the pieces of the puzzling scenario for tumoral cell development and invasion [5]. However, considering that the membrane is necessary for cell formation and reproduction, the ways in which the balance among SFAs, MUFAs and PUFAs influences these steps are still to be defined. MUFAs can be obtained totally by an endogenous process, whereas PUFAs cannot be biosynthesized in humans, as shown in Figure 2B. Due to this "dietary dependency", the effects of an impairment of both exogenous supply and endogenous metabolism needs a comprehensive approach in order to examine cellular metabolism, signaling and nutrition. This is why fatty acid-based membrane lipidomics drives important information in health and diseases and, in particular in cancer "-omics", it is needed for the comprehension of molecular mechanisms and for biomarker discovery. 


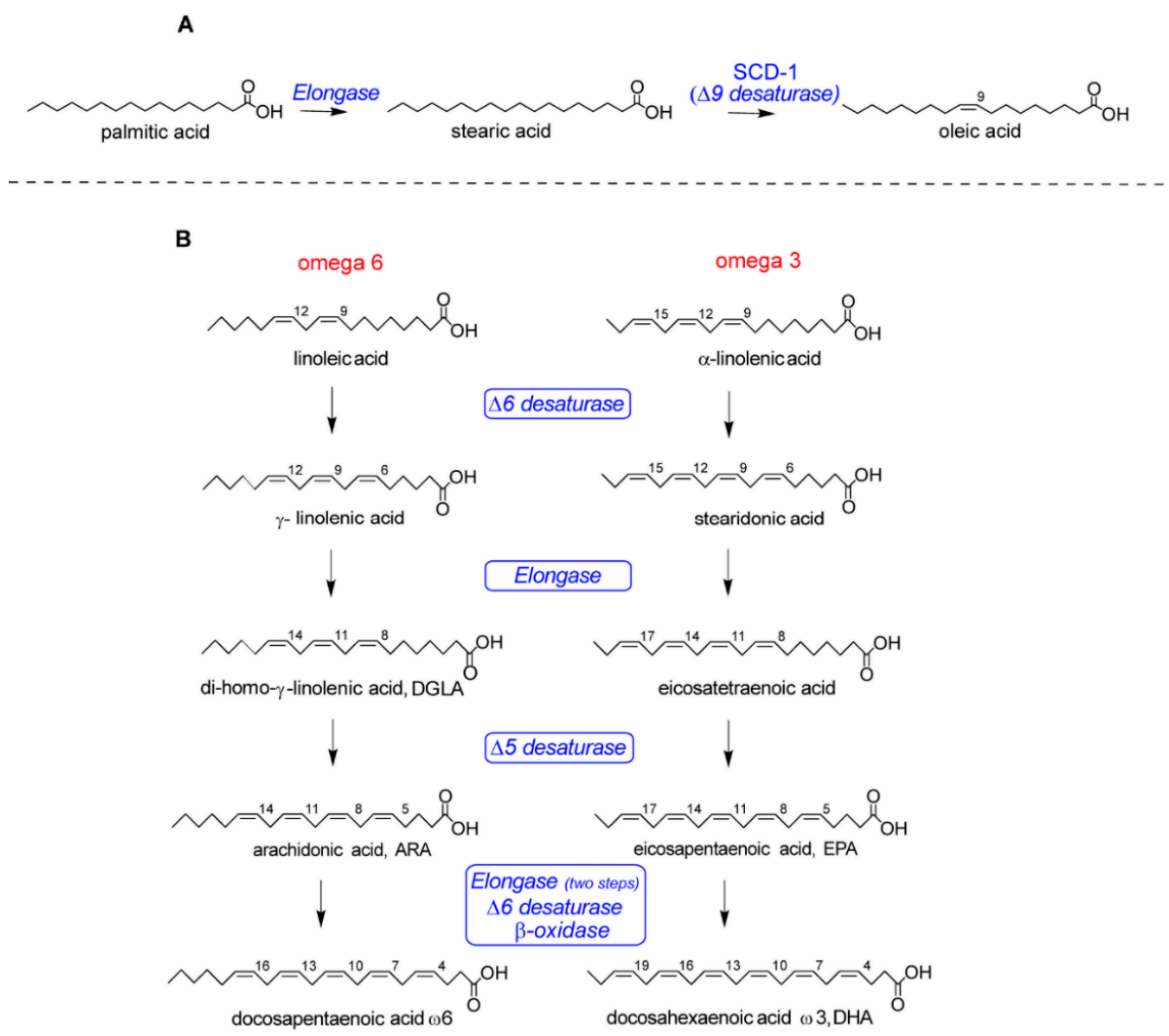

Figure 2. Some metabolic transformations of fatty acids: (A) the saturated fatty acid (SFA), palmitic acid, is transformed into stearic acid and the monounsaturated fatty acid (MUFA), oleic acid; (B) omega-6 and omega-3 precursors taken from the diet are transformed into the other polyunsaturated fatty acids (PUFA) members of the two families.

Here we wish to remark that a multidisciplinary approach is necessary, where chemical, biological and clinical skills are required all at once. Indeed, in membrane lipids research and medical applications, all these skills are also necessary to address critical issues in protocols: are we fully conscious of the difference in monitoring circulating lipids from those entering the cell membrane composition? Can we make crucial decisions about what is the best sampling procedure for cell membrane lipids? Finally, can we make an effort to unify protocols in one accredited procedure, so that big data can be collected and results can be compared in multicentric studies? In our opinion, analytical and chemical competences here come first, since they are required in order to build up accurate and reliable protocols: the recognition of fatty acid structures must be unambiguous [6], as will be shown in this review, taking into account that fatty acids are tissue-specific and each tissue has its own distribution of these molecular components [7]. Quality control must involve the exact separation of fatty acids from the sample to be analyzed, and if membranes are the target, the procedure must isolate them. This accuracy is fundamental because, after analysis, fatty acids are interpreted for their biological effects, as precursors to lipid mediators and contributors to membrane fluidity.

The contribution of fatty acids to membrane properties has been recognized for a long time, particularly in cancer development [8]. More recently, it has been discussed as evidence that the application of membrane modification and manipulation as part of cancer therapeutical strategies is still not developed [9].

An interplay between biosynthesis and diet regulates fatty acid availability. We gathered the literature on how fatty acids are implicated in tumor onset and progression and how the cancer lipidome reflects the activation of the de novo synthetic pathways. In this overview, we wish also to highlight our own work on the discovery of a family of MUFA positional isomers, the n-10 family, 
as new biomarkers of the metabolic shift that allows human cells to build up the first endogenous PUFA component, sebaleic acid [10]. The review also covers the link between obesity and cancer in order to understand why and when lipid supply causes health complications, highlighting specific fatty acids for their biological effects, signaling and contribution to the membrane properties that influence cell growth and death. From this scenario, several hints emerge for innovative strategies in cancer prevention (primary and secondary) using fatty acid-based membrane lipidomics and fatty acid balance.

\section{Fatty Acids and Lipid Supply for Membrane Formation in Cancer}

Cancer is a very complex disease due to the large number of factors involved. Cells develop a great capacity to grow, proliferate and survive under stress conditions. They modify several processes to achieve favorable environments, such as the metabolism of lipids, carbohydrates, proteins and nucleotides, being able to maintain the functionality of the structures and functions [11,12]. Adapted metabolic pathways allow cancer cells to obtain energy, form metabolic intermediates and synthesize fatty acids, even when the exogenous availability of these compounds is reduced. For example, the hyperactivation of the phosphatidylinositol-3 kinase and AKT (PI3K-AKT) transduces the signal from the hormone insulin to drive glucose uptake and is one of the most frequently mutated pathways in cancer [13]. In this case, glycolysis is favored, leading the cells to form pyruvate, which could be used for ATP synthesis or for de novo lipogenesis [14]. The hyperactivation of PI3K-AKT also activates the glutamate pyruvate transaminase 2 (GPT2), favoring glutamine anaplerosis to supply sufficient metabolites for FA synthesis and, finally, remodel the cellular lipidome [15]. In the latter case, it has been shown that such remodeling makes lipids an important hallmark of cancer [16]. The overexpression of FA transporters, such as fatty acid translocase CD36, plasma membrane fatty acid-binding proteins (FABP) and the fatty acid transport protein family (FATP), elevates the uptake of exogenous FAs with their subsequent storage in lipid droplets (LDs), as is known in ovarian cancer, and this is in connection also with adipose tissue, as will be explained in Section 5 [17]. To fully evaluate the lipid supply and understand their role in cancer, we must distinguish between de novo synthesized and dietary fatty acids, as explained below.

\subsection{De Novo Synthesis of Saturated and Monounsaturated Fatty Acids}

Combined with a greater capacity for the biosynthesis of lipids, cancer cells are not only able to maintain lipid homeostasis but also to provide ATP and NADPH in conditions of metabolic stress and sufficient precursors to deal with the formation of lipid rafts that are essential for protein dynamics in membranes and cell survival [18,19]. Since phospholipids are the basic units of membranes, in cancer disease different enzymes involved in their endogenous synthesis are highly expressed, such as ATP-citrate lyase (ACLY), acetyl CoA carboxylase (ACC) and fatty acid synthase (FAS) [20,21]. Each of them represents itself a target of study against cancer. Whereas in nutrient-unlimited and aerobic conditions, the glucose metabolism forms citrate through the tricarboxylic acid cycle (TCA), to later convert into acetyl CoA, being the key for de novo synthesis, cells also develop an alternative strategy to form FA when there is a lack of nutrients and hypoxia (Figure 3). Several groups have proposed that, in these mentioned cases, the TCA cycle can be modified to run in reverse and use glutamine from storage to act as source of acetyl CoA [22,23], whereas others describe that acetyl CoA can be obtained from histone deacetylation [24]. In the case of FAS, in addition, it responds to signals from the activation of the AKT and MAPK (mitogen-activated protein kinase) pathways, which, in turn, are also favored in cancer processes [25]. Besides the fact that the production of FAs is essential to sustain the structure and demands of membranes, their composition is also decisive in guaranteeing the functions of the dividing cells. The production of monounsaturated fatty acids (MUFA) from SFA provides fluidity, functionality and flexibility, which are essential for tumor cells. This step involves the action of delta-9 desaturase enzyme (known also as stearoyl CoA desaturase, SCD-1, and reported in Figure 3), which can act on both palmitic (16:0) and stearic (18:0) acids. As with the enzymatic complex 
from de novo synthesis, SCD-1 is overexpressed in cancer and regulated by different signaling cascades such as MAPK and AKT or systems such as p53 [26], attracting interest in their inhibition $[4,5]$.

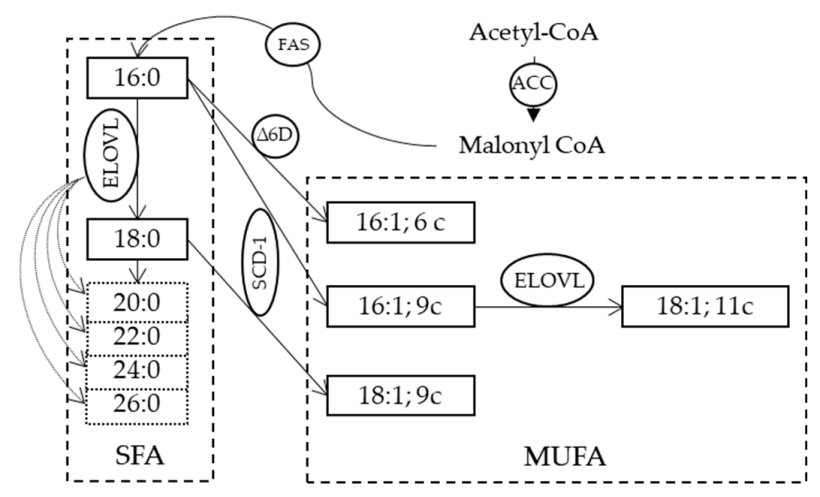

Figure 3. The de novo synthesis of saturated fatty acids (SFA) starting from acetyl CoA and the transformation to monounsaturated fatty acids (MUFA) by two desaturase enzymes. Structures of some of these fatty acids are shown in Figure 1. ACC: acetyl CoA: carboxylase; FAS: fatty acid synthase; ELOVL: elongase enzyme; $\Delta 6 \mathrm{D}$ : delta-6 desaturase $(\Delta 6)$; SCD-1: stearoyl CoA desaturase.

Cancer cells modify lipid metabolism in order to respond to environmental modifications. Hypoxia, for example, affects acetyl CoA formation from glucose and SCD-1 activity, as they are oxygen dependent. However, in this case, tumoral cells escape the need for fatty acid synthesis by increasing the uptake of lysophospholipids as a shortcut to prepare phospholipids. FABPs are transcriptional targets of hypoxia-inducible factors (HIFs) that facilitate extracellular scavenging of long-chain unsaturated lysophospholipids, which can be used as a nutrient source under conditions of metabolic stress [15]. Interestingly, this effect can occur even in aerobic conditions after oncogenic RAS activation, making it independent from SCD-1, to achieve sufficient MUFAs [27]. It is worth highlighting the existing debate about whether fatty acids used by cancer cells are of endogenous or exogenous (dietary) origin, since some studies did not find differences [28]. Lipidomic studies have a fundamental role in the elucidation of the decisive contribution of fatty acid biosynthesis, evidencing storage, lipolysis and membrane remodeling implied in tumor onset, progression and metastasis. Table 1 summarizes the most important fatty acid-driven mechanisms and related biological effects.

Table 1. The main fatty acid-driven mechanisms and biological effects in cancer onset, growth and metastasis.

\begin{tabular}{|c|c|c|c|}
\hline Entry & Implicated Mechanism & Biological Effects & Lit \\
\hline 1 & $\begin{array}{l}\text { Desaturation from } 16: 0 \text { to } 6 c-16: 1 \\
\text { (sapienic acid) }\end{array}$ & Support of membrane biosynthesis during proliferation & {$[29,30]$} \\
\hline 2 & mTORC2 regulation of lipid metabolism & Glycolysis and lipogenesis activation & {$[31,32]$} \\
\hline 3 & $\begin{array}{l}\text { Acetyl CoA synthetase } 2 \text { promotion of } \\
\text { acetate utilization }\end{array}$ & $\begin{array}{l}\text { Maintaining cancer cell growth under hypoxia and metabolic } \\
\text { stress }\end{array}$ & [33] \\
\hline 4 & $\begin{array}{l}\text { Adipokines mediation of ovarian cancer } \\
\text { metastasis }\end{array}$ & Induction of lipolysis and $\beta$-oxidation to provide energy & [34] \\
\hline 5 & $\begin{array}{l}\text { Enhanced uptake of exogenous } \\
\text { lipoproteins }\end{array}$ & $\begin{array}{l}\text { (a) Cholesteryl ester accumulation, induced by PTEN loss and } \\
\text { PI3K/AKT activation, to sustain cancer aggressiveness } \\
\text { (b) Increased amount of cholesterol and overexpression of } \\
\text { low-density lipoprotein receptor to boost proliferation } \\
\text { (c) Sustaining proliferation and aggressive potential of breast } \\
\text { cancer tumors }\end{array}$ & $\begin{array}{l}{[35]} \\
{[36]} \\
{[37]}\end{array}$ \\
\hline 6 & Increase in lipid droplets in tumor cells & $\begin{array}{l}\text { Increased COX-2 expression and storage in droplets, with } \\
\text { effects on proliferation }\end{array}$ & [38] \\
\hline 7 & $\begin{array}{l}\text { Stearoyl CoA desaturase essentiality for } \\
\text { cancer cell survival }\end{array}$ & $\begin{array}{c}\text { Inhibition of FA desaturation, blocking the synthesis of lipids } \\
\text { and impairing cell survival }\end{array}$ & [39] \\
\hline
\end{tabular}


Readers are directed to the original references cited in Table 1 to elaborate on each subject appropriately. Among these mechanisms, a recent one (Entry 1) was individuated by some of our group, investigating the analytical protocols for efficient separation of the MUFA positional isomers, which will be addressed in Section 4. Knowledge of different mechanisms is necessary for research of new therapeutic targets that can act in a synergic manner, to disturb organization of membrane lipids, destabilize lipid rafts and activate apoptosis signaling [18,19].

\subsection{PUFA Intake and Omega-6/Omega-3 Balance for Membrane Fatty Acid-Mediated Signaling}

On the basis of the importance of phospholipids for cell formation, the "membrane hypothesis" can be drawn, for which the initial steps of death or life of tumoral cells could be also driven by the quality of the membrane fatty acids. To create a fatty acid balance among SFA, MUFA and PUFA residues in the individual, it must be taken into account that the dietary intake of omega- 6 and omega-3 regulates the presence of PUFA residues in lipid pools. Once the individual pool is formed, it exerts strong control upon the membrane composition and the types of fatty acids that will be detached from membrane phospholipids to determine the related cell fate. Indeed, the phospholipase $\mathrm{A}_{2}\left(\mathrm{PLA}_{2}\right)$-induced release of fatty acids from membranes is a well-known process, involved in the membrane remodeling cycle, i.e., the Lands cycle [40]. It does not discriminate between omega-3 and omega- 6 structures, thus highlighting the importance of the above-mentioned balance present in membranes for pro- and anti-inflammation signaling. Indeed, every time that the release in the cytoplasm of arachidonic acid from phospholipids occurs by PLA $\mathrm{A}_{2}$, causing the subsequent formation of its eicosanoid mediators, other omega- 6 and omega- 3 fatty acids are released as well, such as di-homo gamma-linolenic acid (DGLA), eicosapentaenoic and docosahexaenoic acids (EPA and DHA). They are, in their turn, precursors of other lipid mediators with mainly anti-inflammatory properties, thus integrating the final inflammation and resolution responses [41]. Obviously, the result depends on the presence and balance of these fatty acids in membranes. Since recent data suggest inflammation as an important aspect in activating cancer proliferation pathways and resistance, it is evident that the membrane predisposition through its fatty acid composition is a piece of information to gather in the puzzling scenario of the cancer disease. Cancer is generated not only by genetic alterations, as a result of intrinsic or exogenous mutagens, but also by long-term exposure to acute or chronic inflammation. It is now becoming clear that the proliferation of cells alone does not cause cancer. However, sustained cell proliferation in an environment rich in inflammatory cells, growth factors and DNA-damage-promoting agents is necessary in the neoplastic process, promoting survival and migration. In this way, the causal relationship that exists between inflammation, innate immunity and cancer is more widely accepted [42]. Many of the molecular and cellular mechanisms that mediate this relationship are still unresolved, but the role that FAs play in inflammation processes related to cancer is increasingly relevant. Indeed, the role of dietary PUFAs omega-6 and omega-3 is a matter for discussion of their effects on cancer incidence and evolution [43]. The negative impact of Western diets, rich in omega-6, has recently been described in societies in which the intake of omega- 6 fatty acids was traditionally in balance with that of omega-3. The number of cases with diseases associated with inflammatory processes, as well as their worse prognosis, has increased [44]. The scientific debate on the importance of the PUFA intake for cancer risk has not yet reached a conclusion. Large population studies are needed to address this task. For example, in a recent population-based (100,881 participants) prospective cohort study, using self-reported dietary data from the Västerbotten Intervention Programme, statistically significant associations have been described between a more anti-inflammatory or healthier diet and reduced risk of cancer [45]. In the development of inflammation mediated by PUFAs, both omega- 6 and omega-3 FAs play crucial roles, since these two families of FAs are in constant competition with each other and, broadly speaking, they develop opposite effects. In this sense, omega-6 FAs are more related to inflammation (through the arachidonic acid (AA) cascade) and omega-3 to anti-inflammatory effects. Figure 2B shows how both omega-3 and omega-6 are closely related, by sharing the same enzymes for each step of their transformations. This fact implies that, from the beginning, there is a need for balance 
between the families, since, if one is favored, it will hinder the synthesis of products from the other. It is worth adding that there are regulations also from the FA-derived mediators' formation and interactions: in the formation of prostaglandins (PG) and leukotrienes (LT) from omega-6 or omega-3 fatty acids, cyclooxygenases (COX-1, COX-2) respond more intensely for intermediates of omega-6 origin in the case of PG (PGD2, PGE2). Furthermore, not only enzymes but also receptors show different affinities, again being favored by PGs and some LTs of the omega-6 series [44]. Thus, in an environment in which omega-6 is biochemically favored, sufficient intake of omega-3 can have a key effect on the PUFA metabolism dynamics, as well as on the intensity of the action of the different eicosanoids. The involvement of PUFAs in cancer is demonstrated here by a few representative examples: regarding omega-6, AA modulates the activation of the nuclear factor kappa-light-chain-enhancer of activated $B$ cells (NF-KB), involved in the immune response and altered in this disease. It also induces focal adhesion kinases, which promote progression and metastasis [46]. The signaling activity of AA is exerted through its transformation to $\mathrm{PGE}_{2}$, and, indeed, the overexpression of COX-2 protein was highlighted in several types of cancer, whereas human breast cancers frequently have high PGE 2 levels, and breast tumors with high COX-2 protein levels are more likely to metastasize [47]. This led to consideration of COX inhibitors for cancer therapies, evaluating also their effects on angiogenesis. In this scenario, the PG interaction with EP receptors (E-series prostaglandin receptors), a family of G-protein coupled receptors designated as EP1-3 and EP4, was individuated, with the corresponding activation or deactivation of the c-AMP cascade or the extracellular signal-regulated kinase (ERK) 1 and ERK2 by way of PI3K [48]. As a matter of fact, not all the omega-6 FAs are equal in the tumor effects, and some studies suggest that, unlike the downstream omega- 6 AA, the upstream omega-6s, such as linoleic acid (LA), $\gamma$-linolenic acid (GLA) and di-homo gamma-linolenic acid (DGLA), may possess anticancer effects. In fact, GLA and DGLA may exert anticancer properties via the production of $\mathrm{PGE}_{1}$. Although more work is needed to clarify the molecular basis of the anticancer effects of GLA and DGLA, it has been demonstrated that they are able to regulate gene and protein expression, disrupting cell-cycle progression and inducing apoptosis, a mechanism which implies also a direct effect on the lipid composition in cell membranes [48]. Regarding omega-3 PUFAs, they have the opposite effect to that mentioned for AA. For example, the combination of EPA and DHA decreases the production of eicosanoids formed from AA, leading to the inactivation of NF- $\mathrm{B}$ and hindering proliferation [46]. They are also able to inhibit the activity of AKT protein, which is involved in cell survival and the inhibition of apoptotic processes [49]. Furthermore, PUFAs are involved in different processes such as lipid peroxidation, cell oxidative stress [50,51] and regulation of gene expression for controlling growth factor mediated carcinogenesis [52]. Moreover, there are other mechanisms involving lipid-based events that affect human health. The interest in ethanolamides has increased, as they are biological compounds that may have important beneficial actions by controlling inflammatory responses without being classical steroidal and non-steroidal anti-inflammatory drugs, that act by inhibiting the cascade of arachidonic acid. Palmitoyl ethanolamide (PEA) is an endogenous lipid mediator that can be found in foods (tomato, soybean, peanut) formed by palmitic acid and ethanolamide, with anti-inflammatory, neuroprotective and analgesic activities [53]. The suggested mechanisms of action involve various metabolic pathways in which some receptors seem to be activated directly (peroxisome proliferator activated receptor alpha (PPAR- $\alpha$ ) and orphan G-protein coupled receptor 55 (GPR55)) or indirectly (cannabinoid receptors, $C_{1}$ and $C_{2}$ ) and transient receptor potential vanilloid type-1 channel (capsaicin receptor or TRPV1)) $[53,54]$ to modulate mast cell activation and degranulation [53]. In colitis-associated cancer, more specifically, PEA inhibits angiogenesis through PPAR- $\alpha$, suggesting a protective effect in both inflammation and cancer, being able to reduce mucosal damage, disease progression and carcinogenesis [55]. To conclude with the PUFA scenario, a brief mention of PUFA peroxidation products and the oxidative-based pathways to induce apoptosis in cancer, including ferroptosis, is made here, directing readers to reported works in these fields [56,57]. 


\section{The Membrane Fatty Acid-Based Profile in Cancer and the Relevance of Erythrocytes}

Considering the importance of fatty acids in membranes, a "bottom-up" approach can reveal the main changes in fatty acid profile between healthy controls and cancer patients. A systematic study of membrane fatty acid-based profiles in large populations is lacking, as is the agreement regarding the biological compartment in which fatty acids are measured. Therefore, there is large heterogeneity of data that does not currently allow us to draw conclusions about the most significant changes occurring in fatty acids in the human body. However, it is important to remark that, from the emerging scenario of fatty acids' involvement in cancer metabolism, it is reasonable to focus the efforts towards the cell membrane compartment. In this respect, the significance of the erythrocyte cell membrane and its fatty acid composition is highlighted for several reasons: (a) the numerosity of erythrocytes and the predominance among other tissues of these cells, which constitute $70-80 \%$ of the total cells formed each day [58], rendering them the best representatives of the availability of fatty acids to construct membrane phospholipids; (b) the continuous exchange of the erythrocyte membrane phospholipids with lipoproteins and tissues in order to reshape the molecular content and satisfy homeostatic requirements [59,60]; (c) the biological mission to reach tissues and organs during the erythrocyte's average life span of four months in humans, which requires the best performance of membrane properties in order to efficiently exchange gases; $(d)$ the presence of the most representative SFA, MUFA and PUFA molecules and the preferred storage of arachidonic acid, known to be present in membrane phospholipids by $13-17 \%$, as well as of other precious PUFAs [6]. Based on these considerations, the fatty acid profile can give information on the balance of these molecular components in erythrocyte phospholipids and help to establish the changes occurring under healthy and unhealthy conditions. Indeed, the fatty acid-based membrane lipidome monitoring used in different human conditions revealed how the endogenously and exogenously-derived fatty acids of erythrocytes are affected [61-64]. In Table 2, the relevant data relating to erythrocyte fatty acid monitoring from studies on cancer patients are gathered, highlighting the cancer types, the country and the number of patients and detailing the most important conclusions of each study. It is interesting to note that the SFA-MUFA transformation emerges as an important biomarker of cancer status, as well as the ratio between omega- 6 and omega-3 PUFAs. 
Table 2. Fatty acids in cancer: collection of data from studies on erythrocyte membrane fatty acids in patients affected by different types of cancer and emerging biomarkers.

\begin{tabular}{|c|c|c|c|c|}
\hline Cancer Type & Country & Human Cohort Size & Outcomes & Reference \\
\hline Breast/Prostate/Liver/Pancreas/Colon/Lung & Puerto Rico & $\begin{array}{l}255 \text { cancer patients } \\
2800 \text { non cancer patients } \\
34 \text { healthy volunteers }\end{array}$ & $\begin{array}{l}\text { Lower levels of stearic acid and increased content of oleic acid. } \\
\text { EPA and DHA/ALA ratio to estimate PUFA imbalances in cancer patients. }\end{array}$ & [65] \\
\hline Colorectal & Japan & $\begin{array}{l}61 \text { cases } \\
42 \text { controls }\end{array}$ & $\begin{array}{l}\text { Less EPA and linoleic acid and high levels of arachidonic acid in } \\
\text { cancer patients. }\end{array}$ & [66] \\
\hline Breast & Italy & $\begin{array}{l}71 \text { cases } \\
141 \text { controls }\end{array}$ & $\begin{array}{l}\text { High oleic acid and low stearic acid in patients. Oleic acid and MUFA } \\
\text { positively associated with breast cancer risk. Saturation index (stearic/oleic } \\
\text { acids ratio) inversely correlated. }\end{array}$ & [67] \\
\hline Colorectal & Italy & $\begin{array}{l}13 \text { cancer patients } \\
13 \text { patients with no } \\
\text { malignant diseases }\end{array}$ & $\begin{array}{l}\text { Lower levels of n-3 PUFAs and higher n-6/n-3 PUFA ratio in } \\
\text { cancer patients. }\end{array}$ & [68] \\
\hline Breast/Colon/Lung & Spain & $\begin{array}{l}54 \text { cases } \\
34 \text { controls }\end{array}$ & $\begin{array}{c}\text { Less SFA (C16:0 and C18:0), high MUFA (9c-C18:1 and 11c-C18:1) } \\
\text { compared to controls. In the PUFA families, increase in n-6 C18:2 and } \\
\text { C20:3 (15.7\% and } 22.2 \% \text {, respectively). }\end{array}$ & [69] \\
\hline Colorectal & France & $\begin{array}{l}328 \text { cases } \\
619 \text { controls }\end{array}$ & $\begin{array}{l}\text { High levels of pentadecanoic and heptadecanoic acids; oleic acid and } \\
\text { linoleic acid associated with the risk of advanced adenomas. } \\
\text { EPA and DHA negatively associated with the risk of advanced adenomas. }\end{array}$ & [70] \\
\hline Basal Cell Carcinoma & Iran & 40 cases, 40 controls & $\begin{array}{l}\text { Low palmitic and high oleic acid levels in cancer patients. Saturation index } \\
\text { (stearic/oleic acids ratio) lower in cancer patients. }\end{array}$ & [71] \\
\hline Basal Cell Carcinoma & Iran & 40 cases, 40 controls & Higher AA, total omega-6 and LA in cancer patients, lower omega-3. & [72] \\
\hline Colorectal & Japan & 74 cases, 221 controls & $\begin{array}{l}\text { Risk of colorectal cancer inversely associated with DHA, AA and PUFAs } \\
\text { and positively associated with palmitic acid, SFAs and SFA/PUFA. }\end{array}$ & [73] \\
\hline Breast & China & 322 cases, 1030 controls & $\begin{array}{l}\text { Significant direct association among palmitic, } \gamma \text {-linolenic, palmitoleic and } \\
\text { vaccenic acids and risk of breast cancer. Total n-3 fatty acids, EPA and } \\
\text { 16:0/16:1 saturation index associated with significantly lower risk of } \\
\text { breast cancer. }\end{array}$ & [74] \\
\hline Prostate & USA & 127 cases, 183 controls & $\begin{array}{l}\text { MUFA and } \alpha \text {-linolenic/EPA ratio associated with reduced risk of } \\
\text { prostate cancer. }\end{array}$ & [75] \\
\hline $\begin{array}{l}\text { Advanced squamous cell lung } \\
\text { carcinoma (SCC), lung } \\
\text { adenocarcinoma (ADC) and small } \\
\text { cell lung cancer (SCLC) }\end{array}$ & Spain & 63 patients, 50 controls & $\begin{array}{l}\text { AA, EPA, palmitic, oleic acids biomarkers in diagnosis and in other aspects } \\
\text { related to clinical disease management of cancer. }\end{array}$ & {$[76]$} \\
\hline
\end{tabular}


From these results, it is also clear that a large multicentric population study would definitely yield important results regarding the adoption of the fatty acid membrane profile for the follow-up of patients and therapies, assessing the importance of fatty acid biomarkers in primary and secondary prevention and discovering the molecular and clinical effects of personalized diets for cancer. We believe that the work in progress to map genetic alterations that control cell-cycle progression, apoptosis and cell growth in cancer [77] can be combined with molecular indicators such as membrane lipidomics in each tumor type to obtain more insights into the lipid pathways in cancer and clarify the epigenetic role of nutrition.

\section{The Study of the Cancer Lipidome and the Discovery of De Novo Pathways: Fatty Acid Positional Isomers as New Biomarkers of Metabolic Shift}

Lipidomics in cancer helps to clarify the connections between disease and lipidome, discovering novel lipid biomarkers for diagnosis as well as alternative and synergic strategies for therapy [78]. As mentioned before, the intake of essential fatty acids (EFA) with the omega-6/omega-3 PUFA balance is of crucial importance since membranes cannot be formed without this supply. The essentiality of PUFA derives from the fact that the insertion of a second double bond in the MUFA structure cannot occur in eukaryotic cells, which means that cells do not have desaturase enzymes able to convert oleic acid (as well as palmitoleic and vaccenic acids) into PUFA in the biosynthesis (see Figures 1 and 3 ). Since neither healthy nor cancerous cells can be formed without PUFA, it can be asked whether the dependence on dietary PUFA is a common feature and a limiting step of both types of cell metabolism. The answer to this question is not as straightforward as it seems, and in fact only recently have investigations been directed toward the study of the influence of metabolism and diet on the human lipidome. In lipidome analysis, it was also discovered that chemical skills are very important to create unambiguous protocols and distinguish fatty acid structures, especially those presenting unsaturations. A seminal example is provided by the report demonstrating for the first time of the presence of sapienic acid in various fractions of human plasma. This is a positional isomer of palmitoleic acid, which has the double bond in C6-C7 instead of C9-C10 [79]. The analytical approach for the unambiguous characterization and discrimination of positional and geometrical fatty acid isomers having the 16:1 structure is crucial for the determination of the sapienic acid presence. We described in detail the protocol of fatty acid analysis, which includes a crucial derivatization step to localize the double bond position, using the well-known dimethyl disulfide (DMDS) adducts and its diagnostic fragmentation in mass spectrometry $[6,10,63,79]$. It must be added that such derivatization procedure and mass spectra can be performed by regular equipment in chemical labs, and do not require specialized and expensive instrumentation. The quantitation of this fatty acid was performed in cholesteryl esters isolated from human plasma of healthy people $(n=5)(50.0 \pm 4.0 \mathrm{ng} / \mathrm{mL})$ and in commercially available human low density lipoprotein (LDL) samples $(35.0 \pm 2.0 \mathrm{ng} / \mathrm{mL})$. How these levels are affected by health conditions in large cohorts remains to be thoroughly explored. These findings prompted us to understand in more detail the biosynthetic origin of sapienic acid. It is reported that, compared to all other types of cells that primarily form oleic acid (Figure 2A), sebocytes change their palmitic acid metabolism by the intervention of delta-6 $(\Delta 6)$ desaturase enzyme (Figure 4) [80]. However, the systemic role of sapienic acid was not explored, and it was not highlighted the crucial step, that is the partition of palmitic acid between SCD-1 and delta-6 desaturase enzymes (see Figure 3). Whether this partition indicates a metabolic diversion with health significance is under current investigation. As a matter of fact, palmitic acid is an unusual substrate for delta- 6 desaturase, which is an enzyme mostly involved with exogenous omega- 6 and omega-3 EFA; therefore, the activation of sapienic acid biosynthesis could be attributed to several reasons, including (a) strong availability of the SFA substrate due to FAS activation, the latter well known in cancer [12,26,81]; (b) enzymatic activity competition or lack of normal intake/ presence of PUFA substrates [80,82]; (c) involvement of enzymatic polymorphism and competitive activity of desaturase for PUFA and SFA metabolisms [83]. Aiming at exploring sapienic acid and the other positional MUFA isomers in cell metabolism, we used the human colon carcinoma 
cell line Caco-2 to compare the results of supplementation of sapienic and palmitoleic acids (150 and $300 \mu \mathrm{M})$, discovering that both are rapidly incorporated into membrane phospholipids and also that the former is converted to 8cis-C18:1 and 5cis, 8cis-18:2, as depicted in Figure 4, bringing also these two fatty acids in the cell membrane phospholipid composition. The $\mathrm{n}-10$ fatty acid family has a still unexplored meaning for cancer cells and we were the first to demonstrate in a cancer cell line that it involves a unique type of endogenous PUFA biosynthesis (i.e., sebaleic acid; Figure 4) leading, more importantly, to its incorporation into membranes.

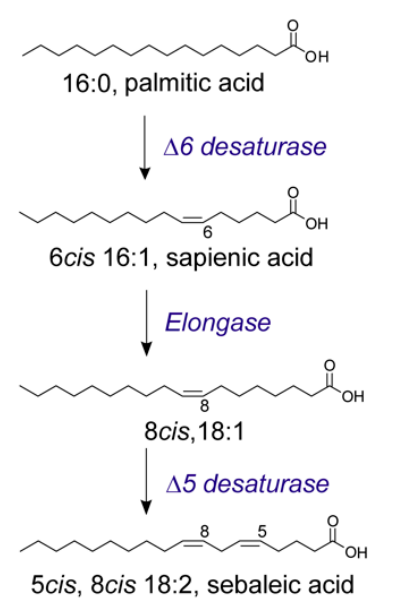

Figure 4. The metabolism of palmitic acid to sapienic acid (6cis-16:1) and its subsequent transformation to obtain the PUFA, sebaleic acid (5cis, 8cis-18:2).

The concomitant isolation of cholesteryl esters and triglycerides from the cell line demonstrated that the n-10 fatty acids "invade" all lipid classes, and, even at high concentrations $(300 \mu \mathrm{M})$ and at long time exposures, they are not harmful (sapienic acid EC ${ }_{50} 232-265 \mu \mathrm{M}$ for $96 \mathrm{~h}$ ) [29]. In the same study, the biophysical properties of the cell membranes were monitored by two-photon fluorescent microscopy, using Laurdan as a dye, showing that the supplementation of sapienic acid, with respect to its positional isomer palmitoleic acid, increased fluidity in several regions, evidently correlated with the formation and distribution of n-10 MUFA and PUFA in lipid domains. Following the interest in extracellular vesicles EVs (exosomes) as relevant sites for cancer metabolism and diagnostics [84], we investigated the presence of the $\mathrm{n}-10$ fatty acid family, comparing membrane phospholipids and EVs of prostate cancer cell lines with different degrees of aggressiveness: PC3 (prostate cancer) and LNCaP (prostate derived from metastatic site: left supraclavicular lymph node), the former being more aggressive [10]. We found that $12-13 \%$ of the membrane fatty acids of these cell lines were composed of $\mathrm{n}-10$ fatty acids, with the sapienic acid content $>7 \%$. In EVs, $n-10$ fatty acids were 9\% for PC3 EVs and 13\% for LNCaP EVs, with statistically significant increases in 8cis-18:1 and 5cis, 8cis-18:2, which is relevant considering that the EV are involved also in the transport of biologically active lipids and lipid metabolites to feed cancer tissues. This discovery can have a strong impact also in cancer diagnostics and follow-up of intervention efficacy. We envisaged that the sapienic/pamitoleic ratio, found equal to 3.5 in prostate cancer cells, also provides a measure of the partition into two metabolic pathways, and, in these cell lines, the delta- 6 desaturase transformation of palmitic acid was found to be unusually high. A parallel evaluation of gene expression for desaturase (FADS) and elongase (ELOVL) enzymes by qRT-PCR (quantitative real time polymerase chain reaction) evidenced significant increases in FADS expression in PC3 with respect to LNCaP cells, and the higher expression of ELOVL5 in PC3 compared to LNCaP cells with ELOVL6 significantly lower. We found interesting evidence of higher desaturase activity in the most aggressive PC3 cell line, and suggested deepening the study of FADS3 desaturase, which, so far, has an uncertain metabolic role [85]. Indeed, the role of desaturase enzymes represents an important aspect in cancer metabolism and is also considered as a target in anticancer therapy, 
as reported in reviews [86] showing these strategies applied in preclinical trials. Regarding elongases, most of them are tumor specific: for example, ELOVL1, ELOVL5, ELOVL6 and ELOVL2 are highly expressed in breast cancer $[87,88]$ and ELOVL7 in prostate cancer [89]. In the new scenario of the n-10 fatty acid family, a recent work confirmed the presence of sapienic acid in different cancer cell lines, defining it as a contributor to cancer plasticity [30], and another paper reported an increase in the transformation of palmitic acid to sapienic acid induced by the increase in mammalian target of rapamycin (mTOR) and sterol regulatory element-binding protein 1 (SREBP-1) signaling in mouse embryonic fibroblasts (MEFs) and U87 glioblastoma cells [90]. In this report, the inhibition of the two signaling pathways led to a decrease in sapienic acid biosynthesis. On the other hand, it must be recalled that fatty acids' enzymatic activities can be influenced by dietary fats, as previously shown for the competition between palmitic acid and PUFA omega- 6 and omega-3 precursors [91].

New pathways involving SFA and MUFA are going to be discovered, provided that analytical protocols are able to give satisfactory results, such as was recently shown by the transformation of oleic acid in MCF7 cell lines into an eicosanoic fatty acid (7cis, 11cis-20:2) obtained by the unusual activity of FADS1 desaturase introducing a double bond at the level of C7 and not C5 [92]. Considering all the published work on the subject, so far only our experiments with cancer cell lines demonstrated the new pathway that brings about endogenous PUFA synthesis (sebaleic acid) and determined the $n-10$ FA insertion at the level of membrane phospholipids. We believe that this outcome of the sapienate metabolism is the real contribution to cancer plasticity, strongly influencing fluidity changes that are deeply embedded in cancer signaling and metabolism. We envisage that the pathway of sapienic acid will have a strong development in metabolic, therapeutic and nutritional research; here, we have provided a careful literature summary of the various contributions available so far, that we hope will be useful to researchers interested in the field.

\section{Link between Obesity and Cancer: When the Lipid Supply Becomes Dangerous}

Despite the difficulty of definitively proving that obesity is one of the causes of cancer, it remains a recognized risk factor contributing to the development and progression of tumors [93]. Several observational studies evidenced that obese and overweight subjects have a higher risk of developing cancer than lean subjects; in 2016, the International Agency for Research on Cancer (IARC) declared that obesity was associated with an increased risk for 13 types of cancer, indicated in Table 3 with their corresponding epidemiological studies [94,95].

Table 3. Increased risk for 13 cancer types correlated to overweight/obesity ( $\%$ increased risk OW/OB vs. lean) and their corresponding epidemiological studies.

\begin{tabular}{ccc}
\hline Cancer Type & Increased Risk (OW/OB vs. Lean) & References \\
\hline Endometrial & $150-200 \%$ & {$[96,97]$} \\
\hline Esophageal & $200-400 \%$ & {$[98,99]$} \\
\hline Gastric cardia & $168-188 \%$ & {$[100,101]$} \\
\hline Liver & $17-89 \%$ & {$[102-104]$} \\
\hline Kidney & $200 \%$ & {$[105-107]$} \\
\hline Multiple myeloma & $10-20 \%$ & {$[108-110]$} \\
\hline Meningioma & $10-20 \%$ & {$[111,112]$} \\
\hline Pancreatic & $50-60 \%$ & {$[113,114]$} \\
\hline Colorectal & $30-60 \%$ & {$[115-117]$} \\
\hline Gallbladder & $20-60 \%$ & {$[118,119]$} \\
\hline Breast & $20-40 \%$ & {$[120-123]$} \\
\hline Ovarian & $10-30 \%$ & {$[97,124]$} \\
\hline Thyroid & $10-30 \%$ & {$[125-127]$} \\
\hline
\end{tabular}


The clarification of the mechanisms binding obesity to cancer is crucial for the diagnosis and implementation of effective therapies. Here, we have gathered the main molecular pathways connecting adipose tissue (AT) and adipocytes with cancer cells in the tumor microenvironment, as well as their impact on cancer growth, invasion and metastasis. We summarize relevant connections between adipose and cancer tissues in Figure 5.

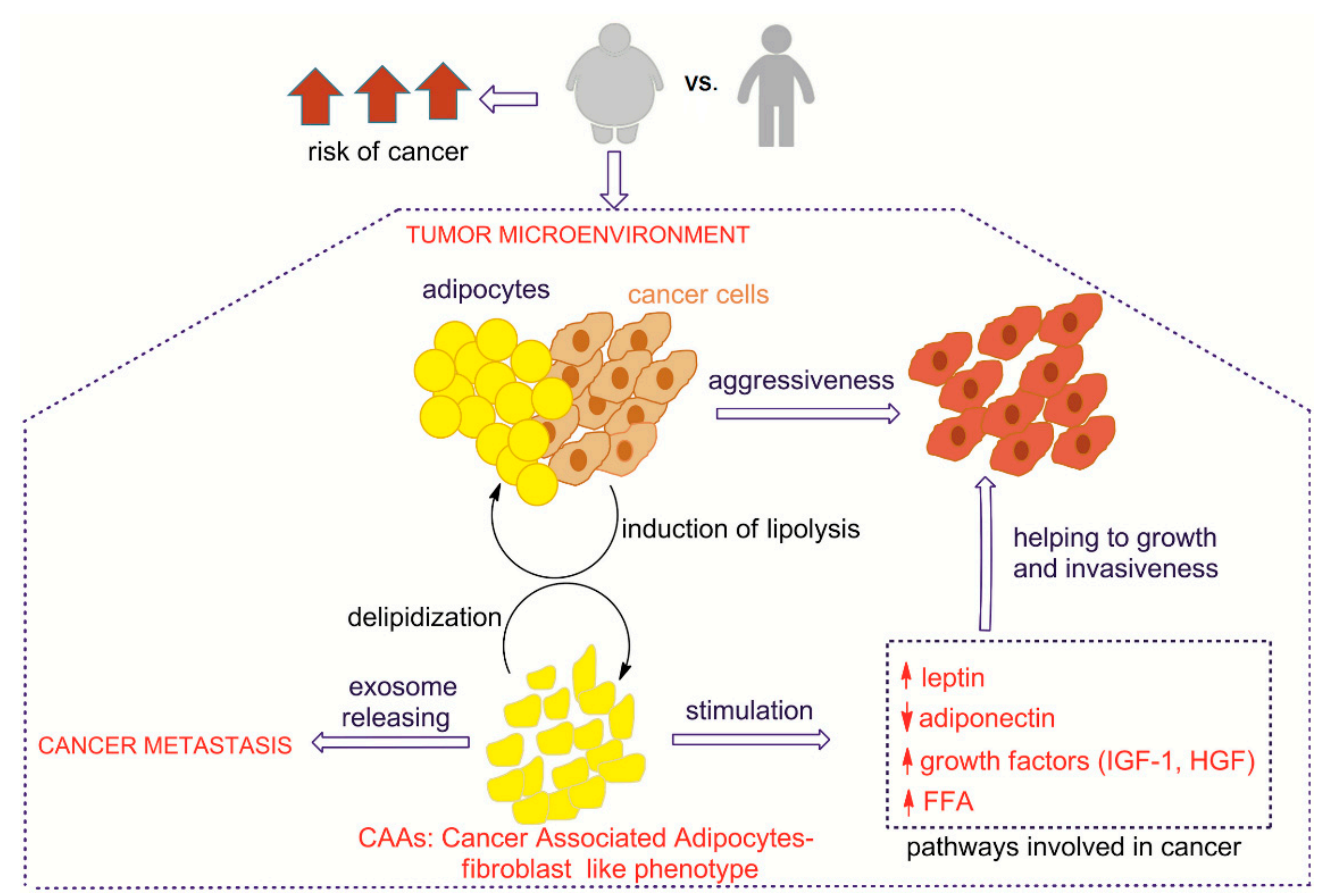

Figure 5. Relevant metabolic connections between adipose and cancer tissues; the arrow $\uparrow$ means increase, the arrow $\downarrow$ means decrease.

The close localization between adipose tissue and cancer cells, immoderately increased in obese subjects due to the effect of excess of calories not consumed, induces a deep modification of the phenotype and functioning of adipocytes, which become cancer-associated adipocytes (CAA), promoted for the induction of lipolysis by cancer cells. Adipocytes are decreased in number and size, showing delipidization and de-differentiation to fibroblast-like phenotype [128-131]. It is well known that the exposure of adipocytes to cancer cells for long periods, with consequent fibroblast morphology, induces the formation of cancer cell fibroblast populations that are involved in tumor invasiveness [132]. In this context, the transformation of adipocytes provides a total alteration of their secretory function involved in endocrine, metabolic and immune systems. The ways in which the specific fatty acid status of adipocytes is involved in the support of cancer cells growth and metastasis are not yet well defined. The identification of several fatty acid unbalances in the erythrocyte membranes of obese patients certainly highlights derangements of lipid metabolism, including the above mentioned sapienic acid pathway [63]. Increased release of free fatty acids accompanies altered levels of adipokines and pro-inflammatory cytokines, growth factors and hormones [133]. The signaling in several types of cancer cells is sustained by adipokines secreted by adipocytes, mainly including leptin, adiponectin, oestrogens, insulin-like growth factor 1 (IGF-1) and hepatocyte growth factor (HGF). In particular, the leptin/adiponectin ratio can be an interesting value to examine, due to the opposite effects of these hormones. Leptin stimulates a cascade of signaling events inducing JAK2/STATs, MAPK/ERK 1/2, PI3K/AKT and PKC, JNK, p38 MAPK and AMPK pathways in diverse cellular types (see abbreviations) [134]. The mechanism implicates the interaction with transmembrane leptin receptor (LRb) that, if phosphorylated, mediates downstream LRb signaling controlling STAT3 (signal transducer and activator of transcription 3) and ERK activation [135,136]. Simultaneously, high levels of leptin induce 
the stimulation of monocytes into macrophages, leading to chronic, obesity-associated inflammation. Leptin increases the expression of anti-apoptotic proteins, inflammatory markers (tumor necrosis factor, TNF- $\alpha$, interleukin IL-6) and angiogenic factors (vascular endothelial growth factor, VEGF), all processes involved in cancer cell survival, proliferation and migration $[137,138]$. On the other hand, adiponectin is inversely correlated to the body mass and cancer, inducing apoptosis and decreasing tumor vascularization. It modulates multiple signaling pathways, exerting its physiological and protective functions through the receptors AdipoR1 and AdipoR2 [139-141]. It is also able to block angiogenesis, inhibiting endothelial cell proliferation induced by FGF2 (fibroblast growth factor 2) as well as the migration of endothelial cells by VEGF. Furthermore, adiponectin inhibits cancer growth and proliferation, interfering with several pathways like AMPK, MAPK and PI3K/AKT, ERK1/2-MAPK pathway and GSK3/catenin, inducing G0/G1 cell-cycle arrest [142-145]. Adiponectin-induced cell death is also accompanied by an increase in intracellular reactive oxygen species (ROS). As a matter of fact, adiponectin pre-treatment suppresses leptin-induced ERK and AKT signaling [146]. Here, we only mention the roles of insulin and glucose levels and their interactions with specific receptors, such as insulin-like growth factor 1 (IGF-1) and hepatocyte growth factor (HGF), that correlate with increased risks of specific cancers, like ovarian and breast cancers, mainly through activation of PI3K/AKT and MAPK pathways [147], while the inhibition of IGF-IR kinase activity prevents the growth-promoting effect of adipocytes on breast cancer cells [148]. Additional factors are connected with the altered environment of adipose tissue and cancer for the increase in inflammatory conditions, with consequent liberation of pro-inflammatory mediators, among them TNF- $\alpha$ and IL-6, contributing to the growth and differentiation in tumors like lymphoma, pancreatic and liver cancers. TNF- $\alpha$ induces carcinogenesis, activating the nuclear transcription factor NF- $\mathrm{KB}$ that prevents apoptosis, allowing enhanced cell survival, growth and proliferation [134,149]. IL-6 is normally elevated in obesity, induces JAK-STAT3 signal transduction and, stimulates cell proliferation, differentiation and metastasis. It mediates cell proliferation through the MAPK pathway; in fact, in some studies, the inhibition of MAPK stopped proliferation in the presence of IL-6, evidencing the role of cytokines in cell proliferation connected with inflammation [150]. Inflammation signaling, as discussed in Section 3, is an important piece of information to acquire in order to estimate factors that trigger cancer and its progression. The need for an integrated metabolic scenario emerges, linking the balance of membrane fatty acid precursors of eicosanoids and other lipid mediators with the effects of fat accumulation and hormonal control.

The effect of transformation of adipocytes in CAAs is evidenced also by increased release of free fatty acids (FFA), with the immediate effect of generating energy to fuel tumor growth [151]. The mobilization of FFA from adipocytes is performed in three steps by lipase enzymes: ATGL (adipose triglycerides lipase), HSL (hormone sensitive lipase) and MAGL (mono acylglycerol lipase), enhancing their circulating levels [93]. Seminal experiments of co-culture of adipocytes with cancer cells showed that there is stimulation of lipolysis in adipocytes releasing FFA and glycerol, with a reduction in adipocyte size [152]. The amount of FFA promoted cancer progression, delivering building blocks for cancer cells but also stimulating lipid metabolism; in ovarian cancer cells, co-cultures with adipocytes induced upregulation of fatty acid $\beta$-oxidation (FAO), with a consequent large quantity of ATP $[133,139,153,154]$, supporting the energy demand of the tumor mass. The transfer process of FFA between adipocytes and cancer cells is mediated by fatty acid-binding protein 4 (FABP4), which supplies energy to the cells and also active oncogenic pathways like IL-6/STAT3/ALDH1, leading to an enhanced stem cell-like phenotype and tumor progression [133]; FABP4 expression increased in cancer cells co-cultivated with adipocytes [155]. The interesting connections of disease development with the fatty acid structures and functions discussed in the previous sections should appear clear at this point, and this review has the scope of stimulating a constructive debate among scientists involved in cancer cell biology, metabolomics and lipidomics in order to use the substantial information available to develop lipid-based diagnostics and strategies for cancer.

The recent results obtained with EVs in cancer offer promising perspectives on mechanistic and diagnostic developments [156]. The transport of lipids by EV from AT can be an important player in 
the whole scenario. In a case study of melanoma, the biomolecular transfer process of EVs seems to increase in the presence of obesity. Incubation of melanoma cells with EVs deriving from AT caused the redistribution of lipid droplets close to mitochondria and the increase of fatty acid oxidation [157]. Research conducted on overweight subjects showed that exosomes derived from cancer cells were incorporated by adipocytes, modifying transcriptome and cytokine secretion; the exosomes obtained from adipocytes strongly helped tumor growth by angiogenesis and enhanced inflammation, recruiting macrophages, activating kinases and involving the NF- $\mathrm{kB}$ signaling pathway $[158,159]$. Together with the analysis of the fatty acid types contained in EVs, including sapienic and sebaleic acids, the EVs have enormous potential for unveiling new aspects of lipid supply to cancer.

Obesity also influences the effects of anticancer therapies, as shown in obese cancer patients compared with non-obese patients evaluated for the effects of the same drug treatment [160]. Besides the various aspects involved in these effects, it is important to highlight that the fatty acid constituents of adipose tissue assume a fundamental role in the modification of pharmacokinetics, conferring drug resistance [161,162].

In the scenario of lipid metabolism, the role of lipophagy (i.e., autophagic degradation of lipid droplets, the main lipid storage organelles of eukaryotic cells), discovered in 2009 to have important consequences on health [163], must be mentioned here, in connection with the ongoing debate concerning the role of fasting strategies in cancer treatment [164]. The ways in which calorie restriction/control impacts obesity and cancer treatment will be matter for further research and active debates from different perspectives [165].

\section{Some Considerations of Fatty Acid-Based Membrane Lipidomics and Lipid Therapy}

Tumoral cells develop accelerated de novo lipogenesis as well as strong lipid recruitment, also taking advantage of obesity, to sustain their needs. However, the quality of fatty acids contributes to their invasiveness, also due to their influence on the biophysical properties of membranes and signaling cascades. The proposal of the "membrane hypothesis" links the initial steps of death or life of tumoral cells with the moment of the phospholipid aggregation for membrane formation and the balance between the saturated and unsaturated fatty acid types present in the individual. This crucial balance is different from tissue to tissue, since each tissue has its own composition [7], and it is important to remark that the membrane formation is a completely spontaneous process of phospholipid aggregation, which in their turn are formed by the availability of fatty acids in the lipid pools. It could be said that, with respect to the adequate intake (AI) of lipids established by the main international agencies of health and food [166], the lipid pool should be able to reach a satisfactory balance, with scarce possibilities for impairment or excess. We are aware of the strong ongoing debate about the interplay between genetics and other causes of cancer [167-170]; however, we wish to highlight the importance of the environment (including nutrition), able to interfere with fatty acid levels and metabolic transformations, with strong impact on inflammatory responses and stress conditions, including on hormonal effects such as explained in obesity (Section 5), that can change the "normal" scenario and create unbalances. In our opinion, it is timely to introduce the monitoring of SFA, MUFA and PUFA membrane levels in clinical practice, in view of evaluating strategies that influence the formation of membranes in the individual. Fatty acid-based membrane lipidomics can give the necessary information to estimate the correctness of the molecular pool, which is the conditio sine qua non for the healthy behavior of this important compartment [61]. It is worth recalling that the erythrocyte membrane compositions of patients under parenteral nutrition reflected the lipid emulsions given to them. In particular, olive oil emulsion was able to induce statistically significantly higher levels of arachidonic acid and omega-6/omega-3 ratio compared to patients treated with a lipid emulsion containing a small percentage of fish oil [64]. This is an important message for those involved in patient care and nutrition and also for considering the exact dosage of fatty acid supplementations for therapeutic purposes. As a matter of fact, membrane homeostasis and related therapies are nowadays emerging, targeting cell membranes by dietary bioactive molecules able to obtain the remodeling of plasma membrane domains. The attenuation 
of oncogenic protein activity by modulating the membrane organization of essential proteins and lipids was proven and this is a promising way to use such an approach to manage cancer expansion. It is worth underlining that omega-3 has a very potent influence on membrane organization and this ability, combined with the anti-inflammatory activity, should be developed toward successful cancer treatments [171,172]. However, it is also evident that, without assessing the membrane status in the individual, the assignment of the lipid strategy cannot be precise, in types and doses, thus even bringing about contrasting clinical outcomes since the membrane unbalance results or remains altered. Therefore, it will be necessary to develop a multidisciplinary approach, involving also clinicians, for the understanding of membrane molecular profiles and for creating protocols of membrane lipidomics and lipid therapy, gathering evidence-based results. In this direction, lipid replacement therapy (LRT) is described as a natural medicine approach to replace damaged lipids in cellular membranes and organelles; however, no personalization is proposed [173]. In the context of membrane therapy, we must also mention natural fatty acids with a structure able to interfere with lipid enzymes, such as sterculic acid, a cyclopropane-containing derivative of oleic acid (9,10-methylene-9-octadecenoic acid) found in plants of the genus Sterculia. This is an inhibitor of SCD-1, and of the related cascades, as previously explained, which has attracted interest for application in various diseases, including cancer [174]. As previously described, lipid enzyme inhibitors (fatty acid synthesis and desaturation) are attracting interest for innovative cancer treatments, and readers are directed to reviews to deepen the state-of-the-art of such therapeutic strategies [15,21,174].

Focusing on mature erythrocytes, their membrane composition data can be gathered from cancer patients, accompanying the biological sample with an accurate food questionnaire. By this approach, we were able to highlight in a preliminary study of cancer patients that they have SFA-MUFA membrane levels which are significantly different from controls and independent of dietary intakes [69]. It is also straightforward that the analytical protocols used for membrane lipidomic analysis must be certified by international accreditation bodies, and it is advisable that such protocols are unified and automatized by high-throughput procedures, in order that clinical laboratories can gather reliable "big data" to depict cancer lipidomics in an incontrovertible manner.

\section{Conclusions}

The acquisition of a multidisciplinary vision of fatty acids' relevance to membrane formation and cancer development is necessary in order to go from the bench to the bedside and to the home of patients, associating nutrient choice with strategies to defeat cancer. The growing understanding of the response of cancer to diet will lead to new therapeutic opportunities but, at the same time, will have practical use in the everyday lives of patients, solving also contrasting effects reported in the literature for PUFA supplementation [175]. It is desirable to increase efforts for a larger understanding of molecular nutrition effects in combination with pharmacology and immunology to control this multifaceted disease [176]. Researchers of several disciplines are required in order to accomplish such goals. Specific effort is needed by clinical units to introduce fatty acid diagnostics tools and therapies to prove the validity of the concepts and translate them into medical practice. Indeed, previously reported clinical effects for some fatty acids, such as the omega- $6 \gamma$-linolenic acid (see Figure 2), of its antitumoral synergy with chemotherapy [177] must take into account its rare presence in foods and be evaluated in a personalized way, also determining the level of this fatty acid in the individual. Therefore, knowledge of molecular diagnostics, such as membrane lipidomics, is a fundamental step toward including endogenous and exogenous fatty acids in the cancer scenario.

Author Contributions: Contributed to data acquisition and writing of the initial version, C.F., A.S., I.T. and J.A.; revision performed, C.F. and R.F. All authors have read and agreed to the published version of the manuscript.

Funding: This work was financially supported by the Centre for the Development of Industrial Technology (CDTI) of the Spanish Ministry of Science and Innovation under the grant agreement TECNOMIFOOD project, CER-20191010. This is contribution number 990 from AZTI. 
Conflicts of Interest: C.F. is co-founder and scientific director of the company Lipinutragen srl, born as spin-off recognized officially by the National Council of Research and involved in research and development of the membrane lipidomic analysis. The company had no role in the design of the study; in the collection and interpretation of data; in the writing of the manuscript, or in the decision to publish the results.

\begin{tabular}{|c|c|}
\hline $\mathrm{AKT}$ & Protein kinase B \\
\hline AMPK & $5^{\prime}$ adenosine monophosphate-activated protein kinase \\
\hline AT & Adipose tissue \\
\hline ATGL & Adipose triglycerides lipase \\
\hline ATP & Adenosine triphosphate \\
\hline CAAs & Cancer-associated adipocytes \\
\hline DMDS & Dimethyl disulfide \\
\hline EFA & Essential fatty acids \\
\hline ERK & Extracellular signal-regulated kinases \\
\hline EVs & Extracellular vesicles \\
\hline FABP & Fatty acid binding protein \\
\hline FADS & Fatty acid desaturase \\
\hline FAO & Fatty acid oxidase \\
\hline FFA & Free fatty acids \\
\hline FGF2 & Fibroblast growth factor 2 \\
\hline GSK3 & Glycogen synthase kinase 3 beta \\
\hline HGF & Hepatocyte growth factor \\
\hline HSL & Hormone sensitive lipase \\
\hline IGF-1 & Insulin growth factor 1 \\
\hline IL-6 & Interleukin 6 \\
\hline JAK2 & Janus kinases 2 \\
\hline JNK & c-Jun N-terminal kinases \\
\hline LDL & Low density lipoproteins \\
\hline LNCAP & Prostate derived from metastatic site \\
\hline LR & Leptin receptor \\
\hline MAGL & Mono acylglycerol lipase \\
\hline MAPK & Mitogen-activated protein kinases \\
\hline MEFs & Mouse embryonic fibroblasts \\
\hline PC3 & Prostate cancer \\
\hline PI3K & Phosphoinositide 3-kinases \\
\hline PKC & Protein kinase $\mathrm{C}$ \\
\hline PPAR & Peroxisome proliferator activated receptor \\
\hline SREBP-1 & Sterol regulatory element- binding protein 1 \\
\hline STAT & Signal transducer and activator of transcription protein \\
\hline STAT3 & Signal transducer and activator of transcription 3 \\
\hline TNF- $\alpha$ & Tumor necrosis factor alpha \\
\hline VEGF & Vascular endothelial growth factor \\
\hline
\end{tabular}

\section{References}

1. Gross, R.W.; Han, X. Lipidomics at the interface of structure and function in systems biology. Chem. Biol. 2011, 18, 284-291. [CrossRef] [PubMed]

2. Abbott, S.K.; Else, P.L.; Atkins, T.A.; Hulbert, A.J. Fatty acid composition of membrane bilayers: Importance of diet polyunsaturated fat balance. Biochim. Biophys. Acta 2012, 1818, 1309-1317. [CrossRef] [PubMed]

3. Chatgilialoglu, C.; Ferreri, C.; Melchiorre, M.; Sansone, A.; Torreggiani, A. Lipid geometrical isomerism: From chemistry to biology and diagnostics. Chem. Rev. 2014, 114, 255-284. [CrossRef] [PubMed]

4. Rohrig, F.; Schulze, A. The multifaceted roles of fatty acid synthesis in cancer. Nat. Rev. Cancer 2016, 16, 732-749. [CrossRef] 
5. Baenke, F.; Peck, B.; Miess, H.; Schulze, A. Hooked on fat: The role of lipid synthesis in cancer metabolism and tumour development. Dis. Model. Mech. 2013, 6, 1353-1363. [CrossRef]

6. Ferreri, C.; Masi, A.; Sansone, A.; Giacometti, G.; Larocca, A.V.; Menounou, G.; Scanferlato, R.; Tortorella, S.; Rota, D.; Conti, M.; et al. Fatty Acids in Membranes as Homeostatic, Metabolic and Nutritional Biomarkers: Recent Advancements in Analytics and Diagnostics. Diagnostics 2017, 7, 1. [CrossRef]

7. Harayama, T.; Riezman, H. Understanding the diversity of membrane lipid composition [published correction appears in Nat Rev Mol Cell Biol. 2019, 20, 715]. Nat. Rev. Mol. Cell Biol. 2018, 19, 281-296. [CrossRef]

8. Nakazawa, I.; Goto, Y. A role of the cellular phospholipid in the metastasis into the liver. Cell. Mol. Biol. 1981, 27, 23-26.

9. Zalba, S.; Ten Hagen, T.L. Cell membrane modulation as adjuvant in cancer therapy. Cancer Treat. Rev. 2017, 52, 48-57. [CrossRef]

10. Ferreri, C.; Sansone, A.; Buratta, S.; Urbanelli, L.; Costanzi, E.; Emiliani, C.; Chatgilialoglu, C. The n-10 Fatty Acids Family in the Lipidome of Human Prostatic Adenocarcinoma Cell Membranes and Extracellular Vesicles. Cancers (Basel) 2020, 12, 900. [CrossRef]

11. Asgari, Y.; Zabihinpour, Z.; Salehzadeh-Yazdi, A.; Schreiber, F.; Masoudi-Nejad, A. Alterations in cancer cell metabolism: The Warburg effect and metabolic adaptation. Genomics 2015, 105, 275-281. [CrossRef] [PubMed]

12. Long, J.; Zhang, C.J.; Zhu, N.; Du, K.; Yin, Y.F.; Tan, X.; Liao, D.F.; Qin, L. Lipid metabolism and carcinogenesis, cancer development. Am. J. Cancer Res. 2018, 8, 778-791.

13. Rabinowitz, J.D.; Coller, H.A. Partners in the Warburg effect. Elife 2016, 5, e15938. [CrossRef]

14. Yeung, S.J.; Pan, J.; Lee, M.H. Roles of p53, MYC and HIF-1 in regulating glycolysis-The seventh hallmark of cancer. Cell. Mol. Life Sci. 2008, 65, 3981-3999. [CrossRef] [PubMed]

15. Koundouros, N.; Poulogiannis, G. Reprogramming of fatty acid metabolism in cancer. Br. J. Cancer 2020, 122, 4-22. [CrossRef]

16. Hanahan, D.; Weinberg, R.A. Hallmarks of cancer: The next generation. Cell 2011, 144, 646-674. [CrossRef] [PubMed]

17. Zhao, G.; Cardenas, H.; Matei, D. Ovarian Cancer-Why Lipids Matter. Cancers 2019, 11, 1870. [CrossRef] [PubMed]

18. Mollinedo, F.; Gajate, C. Lipid rafts as signaling hubs in cancer cell survival/death and invasion: Implications in tumor progression and therapy. J. Lipid Res. 2020, 61, 611-635. [CrossRef]

19. Sviridov, D.; Mukhamedova, N.; Miller, Y.I. Lipid rafts as a therapeutic target. J. Lipid Res. 2020, 6, 687-695. [CrossRef]

20. Currie, E.; Schulze, A.; Zechner, R.; Walther, T.C.; Farese, R.V. Cellular Fatty Acid Metabolism and Cancer. Cell Metabol. 2013, 18, 153-161. [CrossRef]

21. Zhang, J.S.; Lei, J.P.; Wei, G.Q.; Chen, H.; Ma, C.Y.; Jiang, H.Z. Natural fatty acid synthase inhibitors as potent therapeutic agents for cancers: A review. Pharm. Biol. 2016, 54, 1919-1925. [CrossRef] [PubMed]

22. Leonardi, R.; Subramanian, C.; Jackowski, S.; Rock, C.O. Cancer-associated isocitrate dehydrogenase mutations inactivate NADPH-dependent reductive carboxylation. J. Biol. Chem. 2012, 287, 14615-14620. [CrossRef] [PubMed]

23. Marin-Valencia, I.; Yang, C.; Mashimo, T.; Cho, S.; Baek, H.; Yang, X.L.; Rajagopalan, K.N.; Maddie, M.; Vemireddy, V.; Zhao, Z.; et al. Analysis of tumor metabolism reveals mitochondrial glucose oxidation in genetically diverse human glioblastomas in the mouse brain in vivo. Cell Metab. 2012, 15, 827-837. [CrossRef] [PubMed]

24. Comerford, S.A.; Huang, Z.; Du, X.; Wang, Y.; Cai, L.; Witkiewicz, A.K.; Walters, H.; Tantawy, M.N.; Fu, A.; Manning, H.C.; et al. Acetate dependence of tumors. Cell 2014, 159, 1591-1602. [CrossRef] [PubMed]

25. Flavin, R.; Peluso, S.; Nguyen, P.L.; Loda, M. Fatty acid synthase as a potential therapeutic target in cancer. Future Oncol. 2010, 6, 551-562. [CrossRef] [PubMed]

26. Igal, R.A. Stearoyl CoA desaturase-1: New insights into a central regulator of cancer metabolism. Biochim. Biophys. Acta 2016, 1861, 1865-1880. [CrossRef]

27. Kamphorst, J.J.; Cross, J.R.; Fan, J.; De Stanchina, E.; Mathew, R.; White, E.P.; Thompson, C.B.; Rabinowitz, J.D. Hypoxic and Ras-transformed cells support growth by scavenging unsaturated fatty acids from lysophospholipids. Proc. Natl. Acad. Sci. USA 2013, 110, 8882-8887. [CrossRef] 
28. Hopperton, K.E.; Duncan, R.E.; Bazinet, R.P.; Archer, M.C. Fatty acid synthase plays a role in cancer metabolism beyond providing fatty acids for phospholipid synthesis or sustaining elevations in glycolytic activity. Exp. Cell Res. 2014, 320, 302-310. [CrossRef]

29. Scanferlato, R.; Bortolotti, M.; Sansone, A.; Chatgilialoglu, C.; Polito, L.; De Spirito, M.; Maulucci, G.; Bolognesi, A.; Ferreri, C. Hexadecenoic Fatty Acid Positional Isomers and De Novo PUFA Synthesis in Colon Cancer Cells. Int. J. Mol. Sci. 2019, 20, 832. [CrossRef]

30. Vriens, K.; Christen, S.; Parik, S.; Broekaert, D.; Yoshinaga, K.; Talebi, A.; Dehairs, J.; Escalona-Noguero, C.; Schmieder, R.; Cornfield, T.; et al. Evidence for an alternative fatty acid desaturation pathway increasing cancer plasticity. Nature 2019, 566, 403-406. [CrossRef]

31. Guri, Y.; Colombi, M.; Dazert, E.; Hindupur, S.K.; Roszik, J.; Moes, S.; Jenoe, P.; Heim, M.H.; Riezman, I.; Riezman, H.; et al. mTORC2 promotes tumorigenesis via lipid synthesis. Cancer Cell 2017, 32, 807-823. [CrossRef]

32. Hagiwara, A.; Cornu, M.; Cybulski, N.; Polak, P.; Betz, C.; Trapani, F.; Terracciano, L.; Heim, M.H.; Rüegg, M.A.; Hall, M.N. Hepatic mTORC2 activates glycolysis and lipogenesis through Akt, glucokinase, and SREBP1c. Cell Metab. 2012, 15, 725-738. [CrossRef]

33. Schug, Z.T.; Peck, B.; Jones, D.T.; Zhang, Q.; Grosskurth, S.; Alam, I.S.; Goodwin, L.M.; Smethurst, E.; Mason, S.; Blyth, K.; et al. Acetyl-CoA synthetase 2 promotes acetate utilization and maintains cancer cell growth under metabolic stress. Cancer Cell 2015, 27, 57-71. [CrossRef] [PubMed]

34. Nieman, K.M.; Kenny, H.A.; Penicka, C.V.; Ladanyi, A.; Buell-Gutbrod, R.; Zillhardt, M.R.; Romero, I.L.; Carey, M.S.; Mills, G.B.; Hotamisligil, G.S.; et al. Adipocytes promote ovarian cancer metastasis and provide energy for rapid tumor growth. Nat. Med. 2011, 17, 1498-1503. [CrossRef]

35. Yue, S.H.; Li, J.J.; Lee, S.Y.; Lee, H.J.; Shao, T.; Song, B.; Cheng, L.; Masterson, T.A.; Liu, X.Q.; Ratliff, T.L.; et al. Cholesteryl Ester Accumulation Induced by PTEN Loss and PI3K/AKT Activation Underlies Human Prostate Cancer Aggressiveness. Cell Metab. 2014, 19, 393-406. [CrossRef] [PubMed]

36. Guillaumond, F.; Bidaut, G.; Ouaissi, M.; Servais, S.; Gouirand, V.; Olivares, O.; Lac, S.; Borge, L.; Roques, J.; Gayet, O.; et al. Cholesterol uptake disruption, in association with chemotherapy, is a promising combined metabolic therapy for pancreatic adenocarcinoma. Proc. Natl. Acad. Sci. USA 2015, 112, 2473-2478. [CrossRef] [PubMed]

37. De Gonzalo-Calvo, D.; Lopez-Vilaro, L.; Nasarre, L.; Perez-Olabarria, M.; Vazquez, T.; Escuin, D.; Badimon, L.; Barnadas, A.; Lerma, E.; Llorente-Cortes, V. Intratumor cholesteryl ester accumulation is associated with human breast cancer proliferation and aggressive potential: A molecular and clinicopathological study. BMC Cancer 2015, 15, 460. [CrossRef]

38. Accioly, M.T.; Pacheco, P.; Maya-Monteiro, C.M.; Carrossini, N.; Robbs, B.K.; Oliveira, S.S.; Kaufmann, C.; Morgado-Diaz, J.A.; Bozza, P.T.; Viola, J.P.B. Lipid bodies are reservoirs of cyclooxygenase-2 and sites of prostaglandin-E-2 synthesis in colon cancer cells. Cancer Res. 2008, 68, 1732-1740. [CrossRef]

39. Peck, B.; Schug, Z.T.; Zhang, Q.F.; Dankworth, B.; Jones, D.T.; Smethurst, E.; Patel, R.; Mason, S.; Jiang, M.; Saunders, R.; et al. Inhibition of fatty acid desaturation is detrimental to cancer cell survival in metabolically compromised environments. Cancer Metab. 2016, 4, 6. [CrossRef]

40. Tontonoz, P.; Wang, B. Phospholipid remodeling in physiology and disease. Ann. Rev. Physiol. 2019, 81, 165-188.

41. Serhan, C.N. Novel pro-resolving lipid mediators in inflammation are leads for resolution physiology. Nature 2014, 510, 92-101. [CrossRef] [PubMed]

42. Coussens, L.M.; Werb, Z. Inflammation and cancer. Nature 2002, 420, 860-867. [CrossRef] [PubMed]

43. MacLean, C.H.; Newberry, S.J.; Mojica, W.A.; Khanna, P.; Issa, A.M.; Suttorp, M.J.; Lim, Y.W.; Traina, S.B.; Hilton, L.; Garland, R.; et al. Effects of omega-3 fatty acids on cancer risk: A systematic review. JAMA 2006, 295, 403-415. [CrossRef] [PubMed]

44. Lands, B. Omega-3 PUFAs lower the propensity for arachidonic acid cascade overreactions. BioMed Res. Int. 2015, 2015, 285135. [CrossRef]

45. Bodén, S.; Myte, R.; Wennberg, M.; Harlid, S.; Johansson, I.; Shivappa, N.; Hébert, J.R.; Van Guelpen, B.; Nilsson, L.M. The inflammatory potential of diet in determining cancer risk; A prospective investigation of two dietary pattern scores. PLoS ONE 2019, 14, e0214551. [CrossRef]

46. Calder, P.C. n-3 fatty acids, inflammation and immunity: New mechanisms to explain old actions. Proc. Nutr. Soc. 2013, 72, 326-336. [CrossRef] 
47. Ristimaki, A.; Sivula, A.; Lundin, J.; Lundin, M.; Salminen, T.; Haglund, C.; Joensuu, H.; Isola, J. Prognostic significance of elevated cyclooxygenase-2 expression in breast cancer. Cancer Res. 2002, 62, 632-635.

48. Xu, Y.; Qian, S.Y. Anti-cancer activities of $\omega-6$ polyunsaturated fatty acids. Biomed. J. 2014, 37, 112-119.

49. Zanoaga, O.; Jurj, A.; Raduly, L.; Cojocneanu-Petric, R.; Fuentes-Mattei, E.; Wu, O.; Braicu, C.; Gherman, C.D.; Berindan-Neagoe, I. Implications of dietary omega-3 and omega-6 polyunsaturated fatty acids in breast cancer (Review). Exp. Ther. Med. 2018, 15, 1167-1176. [CrossRef]

50. Larsson, S.C.; Kumlin, M.; Ingelman-Sundberg, M.; Wolk, A. Dietary long-chain n-3 fatty acids for the prevention of cancer: A review of potential mechanisms. Am. J. Clin. Nutr. 2004, 79, 935-945. [CrossRef]

51. Ferreri, C.; Chatgilialoglu, C. Lipidomics and Health: An Added Value to Olive Oil. In Olives and Olive Oil as Functional Foods: Bioactivity, Chemistry and Processing, 1st ed.; Shahidi, P., Kiritsakis, P., Eds.; Wiley: Chichester, UK, 2017; Chapter 27; pp. 505-520.

52. Schley, P.D.; Brindley, D.N.; Field, C.J. (n-3) PUFA alter raft lipid composition and decrease epidermal growth factor receptor levels in lipid rafts of human breast cancer cells. J. Nutr. 2007, 137, 548-553. [CrossRef] [PubMed]

53. Petrosino, S.; Di Marzo, V. The pharmacology of palmitoylethanolamide and first data on the therapeutic efficacy of some of its new formulations. Br. J. Pharmacol. 2017, 174, 1349-1365. [CrossRef] [PubMed]

54. De Petrocellis, L.; Bisogno, T.; Ligresti, A.; Bifulco, M.; Melck, D.; Di Marzo, V. Effect on cancer cell proliferation of palmitoylethanolamide, a fatty acid amide interacting with both the cannabinoid and vanilloid signalling systems. Fundam. Clin. Pharmacol. 2002, 16, 297-302. [CrossRef]

55. Sarnelli, G.; D’Alessandro, A.; Iuvone, T.; Capoccia, E.; Gigli, S.; Pesce, M.; Seguella, L.; Nobile, N.; Aprea, G.; Maione, F.; et al. Palmitoylethanolamide Modulates Inflammation-Associated Vascular Endothelial Growth Factor (VEGF) Signaling via the Akt/mTOR Pathway in a Selective Peroxisome Proliferator-Activated Receptor Alpha (PPAR- $\alpha$ )-Dependent Manner. PLoS ONE 2016, 11, e0156198. [CrossRef] [PubMed]

56. Friedmann Angeli, J.P.; Krysko, D.V.; Conrad, M. Ferroptosis at the crossroads of cancer-acquired drug resistance and immune evasion. Nat. Rev. Cancer 2019, 19, 405-414. [CrossRef] [PubMed]

57. Conrad, M.; Pratt, D.A. The chemical basis of ferroptosis [published correction appears in Nat Chem Biol. 2020 Jan 2]. Nat. Chem. Biol. 2019, 15, 1137-1147. [CrossRef] [PubMed]

58. Sender, R.; Fuchs, S.; Milo, R. Revised estimates for the number of human and bacteria cells in the body. PLoS Biol. 2016, 14, e1002533. [CrossRef]

59. Reed, C.F. Phospholipid exchange between plasma and erythrocytes in man and the dog. J. Clin. Investig. 1968, 47, 749-760. [CrossRef]

60. Dushianthan, A.; Cusack, R.; Koster, G.; Grocott, M.P.W.; Postle, A.D. Insight into erythrocyte phospholipid molecular flux in healthy humans and in patients with acute respiratory distress syndrome. PLOS ONE 2019, 14, e0221595. [CrossRef]

61. Ferreri, C.; Chatgilialoglu, C. Membrane Lipidomics for Personalized Health; Wiley: Chichester, UK, 2015.

62. Giacometti, G.; Ferreri, C.; Sansone, A.; Chatgilialoglu, C.; Marzetti, C.; Spyratou, E.; Georgakilas, A.G.; Marini, M.; Abruzzo, P.M.; Bolotta, A.; et al. High predictive values of rbc membrane-based diagnostics by biophotonics in an integrated approach for autism spectrum disorders. Sci. Rep. 2017, 7, 9854. [CrossRef]

63. Sansone, A.; Tolika, E.; Louka, M.; Sunda, V.; Deplano, S.; Melchiorre, M.; Anagnostopoulos, D.; Chatgilialoglu, C.; Formisano, C.; Di Micco, R.; et al. Hexadecenoic fatty acid isomers in human blood lipids and their relevance for the interpretation of lipidomic profiles. PLOS ONE 2016, 11, e0152378. [CrossRef]

64. Pironi, L.; Guidetti, M.; Verrastro, O.; Iacona, C.; Agostini, F.; Pazzeschi, C.; Sasdelli, A.S.; Melchiorre, M.; Ferreri, C. Functional lipidomics in patients on home parenteral nutrition: Effect of lipid emulsions. World J. Gastroenterol. 2017, 23, 4604-4614. [CrossRef] [PubMed]

65. Mikirova, N.; Riordan, H.D.; Jackson, J.A.; Wong, K.; Miranda-Massari, J.R.; Gonzalez, M.J. Erythrocyte membrane fatty acid composition in cancer patients. P. R. Health Sci. J. 2004, 23, 107-113.

66. Okunoi, M.; Hamazaki, K.; Ogura, T.; Kitade, H.; Matsuura, T.; Yoshida, R.; Hijikawa, T.; Kwon, M.; Arita, S.; Itomura, M.; et al. Abnormalities in Fatty Acids in Plasma, Erythrocytes and Adipose Tissue in Japanese Patients with Colorectal Cancer. In Vivo 2013, 27, 203-210.

67. Pala, V.; Krogh, V.; Muti, P.; Chajes, V.; Riboli, E.; Micheli, A.; Saadatian, M.; Sieri, S.; Berrino, F. Erythrocyte membrane fatty acids and subsequent breast cancer: A prospective Italian study. J. Natl. Cancer Inst. 2001, 93, 1088-1095. [CrossRef] [PubMed] 
68. Coviello, G.; Tutino, V.; Notarnicola, M.; Caruso, M.G. Erythrocyte Membrane Fatty Acids Profile in Colorectal Cancer Patients: A Preliminary Study. Anticancer Res. 2014, 34, 4775-4779. [PubMed]

69. Amézaga, J.; Arranz, S.; Urruticoechea, A.; Ugartemendia, G.; Larraioz, A.; Louka, M.; Uriarte, M.; Ferreri, C.; Tueros, I. Altered red blood cell membrane fatty acid profile in cancer patients. Nutrients 2018, 10, 1853. [CrossRef] [PubMed]

70. Cottet, V.; Collin, M.; Gross, A.S.; Boutron-Ruault, M.C.; Morois, S.; Clavel-Chapelon, F.; Chajes, V. Erythrocyte membrane phospholipid fatty acid concentrations and risk of colorectal adenomas: A case-control nested in the French E3N-EPIC cohort study. Cancer Epidemiol. Biomark. Prev. 2013, 22, 1417-1427. [CrossRef] [PubMed]

71. Rahrovani, F.; Javanbakht, M.H.; Ehsani, A.H.; Esrafili, A.; Mohammadi, H.; Ghaedi, E.; Zarei, M.; Djalali, M. Erythrocyte membrane saturated fatty acids profile in newly diagnosed Basal Cell Carcinoma patients. Clin. Nutr. Espen 2018, 23, 107-111. [CrossRef] [PubMed]

72. Rahrovani, F.; Javanbakht, M.H.; Ghaedi, E.; Mohammadi, H.; Ehsani, A.H.; Esrafili, A.; Djalali, M. Erythrocyte Membrane Unsaturated (Mono and Poly) Fatty Acids Profile in Newly Diagnosed Basal Cell Carcinoma Patients. Clin. Nutr. Res. 2018, 7, 21-30. [CrossRef]

73. Kuriki, K.; Wakai, K.; Hirose, K.; Matsuo, K.; Ito, H.; Suzuki, T.; Saito, T.; Kanemitsu, Y.; Hirai, T.; Kato, T.; et al. Risk of colorectal cancer is linked to erythrocyte compositions of fatty acids as biomarkers for dietary intakes of fish, fat, and fatty acids. Cancer Epidemiol. Biomark. Prev. 2006, 15, 1791-1798. [CrossRef] [PubMed]

74. Shannon, J.; King, I.B.; Moshofsky, R.; Lampe, J.W.; Gao, D.L.; Ray, R.M.; Thomas, D.B. Erythrocyte fatty acids and breast cancer risk: A case-control study in Shanghai, China. Am. J. Clin. Nutr. 2007, 85, 1090-1097. [CrossRef] [PubMed]

75. Shannon, J.; O’Malley, J.; Mori, M.; Garzotto, M.; Palma, A.J.; King, I.B. Erythrocyte fatty acids and prostate cancer risk: A comparison of methods. Prostaglandins Leukot. Essent. Fatty Acids 2010, 83, 161-169. [CrossRef]

76. Sanchez-Rodriguez, P.; Rodriguez, M.C.; Sanchez-Yague, J. Identification of potential erythrocyte phospholipid fatty acid biomarkers of advanced lung adenocarcinoma, squamous cell lung carcinoma, and small cell lung cancer. Tumor Biol. 2015, 36, 5687-5698. [CrossRef]

77. Sanchez-Vega, F.; Mina, M.; Armenia, J.; Chatila, W.; Luna, A.; La, K.C.; Dimitriadoy, S.; Liu, D.L.; Kantheti, H.S.; Saghafinia, S.; et al. Oncogenic signaling in the cancer genome atlas. Cell 2018, 173, 321-337. [CrossRef]

78. Stromberg, L.R.; Lilley, L.M.; Mukundan, H. Advances in Lipidomics for Cancer Biomarker Discovery. In Proteomic and Metabolomic Approaches to Biomarker Discovery; Academic Press: Cambridge, MA, USA, 2020; pp. 421-436. [CrossRef]

79. Sansone, A.; Melchiorre, M.; Chatgilialoglu, C.; Ferreri, C. Hexadecenoic Fatty Acid Isomers: A Chemical Biology Approach for Human Plasma Biomarker Development. Chem. Res. Toxicol. 2013, 26, 1703-1709. [CrossRef]

80. Ge, L.; Gordon, J.S.; Hsuan, C.; Stenn, K.; Prouty, S.M. Identification of the Delta-6 desaturase of human sebaceous glands: Expression and enzyme activity. J. Invest. Dermatol. 2003, 120, 707-714. [CrossRef]

81. Igal, R.A. Stearoyl-CoA desaturase-1: A novel key player in the mechanisms of cell proliferation, programmed cell death and transformation to cancer. Carcinogenesis 2010, 31, 1509-1515. [CrossRef]

82. Pappas, A.; Anthonavage, M.; Gordon, J.S. Metabolic fate and selective utilization of major fatty acids in human sebaceous gland. J. Invest. Dermatol. 2002, 118, 164-171. [CrossRef]

83. Zhang, J.Y.; Kothapalli, K.S.D.; Brenna, J.T. Desaturase and elongase-limiting endogenous long-chain polyunsaturated fatty acid biosynthesis. Curr. Opin. Clin. Nutr. Metab. Care 2016, 19, 103-110. [CrossRef] [PubMed]

84. Sahebi, R.; Langari, H.; Fathinezhad, Z.; Bahari Sani, Z.; Avan, A.; Mobarhan, M.G.; Rezayi, M. Exosomes: New insights into cancer mechanisms. J. Cell. Biochem. 2020, 121, 7-16. [CrossRef]

85. Lattka, E.; Illig, T.; Koletzko, B.; Heinrich, J. Genetic variants of the FADS1 FADS2 gene cluster as related to essential fatty acid metabolism. Curr. Opin. Lipidol. 2010, 21, 64-69. [CrossRef] [PubMed]

86. Tracz-Gaszewska, Z.; Dobrzyn, P. Stearoyl-CoA Desaturase 1 as a Therapeutic Target for the Treatment of Cancer. Cancers 2019, 11, 948. [CrossRef] [PubMed]

87. Yamashita, Y.; Nishiumi, S.; Kono, S.; Takao, S.; Azuma, T.; Yoshida, M. Differences in elongation of very long chain fatty acids and fatty acid metabolism between triple-negative and hormone receptor-positive breast cancer. BMC Cancer 2017, 17, 589. [CrossRef] [PubMed] 
88. Gonzalez-Bengtsson, A.; Asadi, A.; Gao, H.; Dahlman-Wright, K.; Jacobsson, A. Estrogen Enhances the Expression of the Polyunsaturated Fatty Acid Elongase Elovl2 via ERa in Breast Cancer Cells. PLoS ONE 2016, 11, e0164241. [CrossRef]

89. Tamura, K.; Makino, A.; Hullin-Matsuda, F.; Kobayashi, T.; Furihata, M.; Chung, S.; Ashida, S.; Miki, T.; Fujioka, T.; Shuin, T.; et al. Novel Lipogenic Enzyme ELOVL7 Is Involved in Prostate Cancer Growth through Saturated Long-Chain Fatty Acid Metabolism. Cancer Res. 2009, 69, 8133-8140. [CrossRef]

90. Triki, M.; Rinaldi, G.; Planque, M.; Broekaert, D.; Winkelkotte, A.M.; Maier, C.R.; Raman, S.J.; Vandekeere, A.; Van Elsen, J.; Orth, M.F.; et al. mTOR Signaling and SREBP Activity Increase FADS2 Expression and Can Activate Sapienate Biosynthesis. Cell Rep. 2020, 31, 1-9. [CrossRef]

91. Park, H.G.; Kothapalli, K.S.D.; Park, W.J.; DeAllie, C.; Liu, L.; Liang, A.; Lawrence, P.; Brenna, J.T. Palmitic acid (16:0) competes with omega-6 linoleic and omega-3 alpha-linolenic acids for FADS2 mediated Delta 6-desaturation. BBA. Mol. Cell Biol. Lipids 2016, 1861, 91-97. [CrossRef]

92. Park, H.G.; Engel, M.G.; Vogt-Lowell, K.; Lawrence, P.; Kothapalli, K.S.; Brenna, J.T. The role of fatty acid desaturase (FADS) genes in oleic acid metabolism: FADS1 Delta 7 desaturates 11-20:1 to 7,11-20:2. Prostaglandins Leukot. Essent. Fatty Acids 2018, 128, 21-25. [CrossRef]

93. Khandekar, M.J.; Cohen, P.; Spiegelman, B.M. Molecular mechanisms of cancer development in obesity. Nat. Rev. Cancer 2011, 11, 886-895. [CrossRef]

94. Ligibel, J.A.; Wollins, D. American Society of Clinical Oncology Obesity Initiative: Rationale, Progress, and Future Directions. J. Clin. Oncol. 2016, 34, 4256-4260. [CrossRef] [PubMed]

95. Gutierrez-Salmeron, M.; Chocarro-Calvo, A.; Garcia-Martinez, J.M.; De la Vieja, A.; Garcia-Jimenez, C. Epidemiological bases and molecular mechanisms linking obesity, diabetes, and cancer. Endocrinol. Diabetes Y Nutr. 2017, 64, 109-117. [CrossRef]

96. Shaw, E.; Farris, M.; McNeil, J.; Friedenreich, C. Obesity and Endometrial Cancer. In Obesity and Cancer. Recent Results in Cancer Research; Pischon, T., Nimptsch, K., Eds.; Springer: Cham, Switzerland, 2016; Volume 208. [CrossRef]

97. Feng, Y.H. The association between obesity and gynecological cancer. Gynecol. Minim. Invasive Ther. Gmit 2015, 4, 102-105. [CrossRef]

98. Hoyo, C.; Cook, M.B.; Kamangar, F.; Freedman, N.D.; Whiteman, D.C.; Bernstein, L.; Brown, L.M.; Risch, H.A.; Ye, W.M.; Sharp, L.; et al. Body mass index in relation to oesophageal and oesophagogastric junction adenocarcinomas: A pooled analysis from the International BEACON Consortium. Int. J. Epidemiol. 2012, 41, 1706-1718. [CrossRef] [PubMed]

99. Schlottmann, F.; Dreifuss, N.H.; Patti, M.G. Obesity and esophageal cancer: GERD, Barrett's esophagus, and molecular carcinogenic pathways. Exp. Rev. Gastroent. Hepatol. 2020, 14, 425-433. [CrossRef]

100. Chen, Y.; Liu, L.X.; Wang, X.L.; Wang, J.H.; Yan, Z.P.; Cheng, J.M.; Gong, G.Q.; Li, G.P. Body Mass Index and Risk of Gastric Cancer: A Meta-analysis of a Population with More Than Ten Million from 24 Prospective Studies. Cancer Epidemiol. Biomark. Prev. 2013, 22, 1395-1408. [CrossRef]

101. Du, X.; Hidayat, K.; Shi, B.M. Abdominal obesity and gastroesophageal cancer risk: Systematic review and meta-analysis of prospective studies. Biosci. Rep. 2017, 37, BSR20160474. [CrossRef]

102. Olefson, S.; Moss, S.F. Obesity and related risk factors in gastric cardia adenocarcinoma. Gastric Cancer 2015, 18, 23-32. [CrossRef]

103. Saitta, C.; Pollicino, T.; Raimondo, G. Obesity and liver cancer. Ann. Hepatol. 2019, 18, 810-815. [CrossRef]

104. Rahmani, J.; Varkaneh, H.K.; Kontogiannis, V.; Ryan, P.M.; Bawadi, H.; Fatahi, S.; Zhang, Y. Waist Circumference and Risk of Liver Cancer: A Systematic Review and Meta-Analysis of over 2 Million Cohort Study Participants. Liver Cancer 2020, 9, 6-14. [CrossRef]

105. Wilson, K.M.; Cho, E. Obesity and Kidney Cancer Recent Results. Cancer Res. 2016, 208, 81-93.

106. Sanfilippo, K.M.; McTigue, K.M.; Fidler, C.J.; Neaton, J.D.; Chang, Y.F.; Fried, L.F.; Liu, S.M.; Kuller, L.H. Hypertension and Obesity and the Risk of Kidney Cancer in 2 Large Cohorts of US Men and Women. Hypertension 2014, 63, 934-941. [CrossRef] [PubMed]

107. Wang, F.R.; Xu, Y.H. Body mass index and risk of renal cell cancer: A dose-response meta-analysis of published cohort studies. Int. J. Cancer 2014, 135, 1673-1686. [CrossRef] 
108. Thordardottir, M.; Lindqvist, E.K.; Lund, S.H.; Costello, R.; Burton, D.; Korde, N.; Mailankody, S.; Eiriksdottir, G.; Launer, L.J.; Gudnason, V.; et al. Obesity and risk of monoclonal gammopathy of undetermined significance and progression to multiple myeloma: A population-based study. Blood Adv. 2017, 1, 2186-2192. [CrossRef]

109. Wallin, A.; Larsson, S.C. Body mass index and risk of multiple myeloma: A meta-analysis of prospective studies. Eur. J. Cancer 2011, 47, 1606-1615. [CrossRef]

110. Bullwinkle, E.M.; Parker, M.D.; Bonan, N.F.; Falkenberg, L.G.; Davison, S.P.; DeCicco-Skinner, K.L. Adipocytes contribute to the growth and progression of multiple myeloma: Unraveling obesity related differences in adipocyte signaling. Cancer Lett. 2016, 380, 114-121. [CrossRef]

111. Niedermaier, T.; Behrens, G.; Schmid, D.; Schlecht, I.; Fischer, B.; Leitzmann, M.F. Body mass index, physical activity, and risk of adult meningioma and glioma. A meta-analysis. Neurology 2015, 85, 1342-1350. [CrossRef]

112. Rutkowski, R.; Reszec, J.; Hermanowicz, A.; Chrzanowski, R.; Lyson, T.; Mariak, Z.; Chyczewski, L. Correlation of leptin receptor expression with BMI in differential grades of human meningiomas. Oncol. Lett. 2016, 11, 2515-2519. [CrossRef]

113. Genkinger, J.M.; Spiegelman, D.; Anderson, K.E.; Bernstein, L.; Van den Brandt, P.A.; Calle, E.E.; English, D.R.; Folsom, A.R.; Freudenheim, J.L.; Fuchs, C.S.; et al. A pooled analysis of 14 cohort studies of anthropometric factors and pancreatic cancer risk. Int. J. Cancer 2011, 129, 1708-1717. [CrossRef]

114. Xu, M.; Jung, X.M.; Hines, O.J.; Eibl, G.; Chen, Y.J. Obesity and pancreatic cancer overview of epidemiology and potential prevention by weight loss. Pancreas 2018, 47, 158-162. [CrossRef]

115. Liu, P.H.; Wu, K.; Ng, K.; Zauber, A.G.; Nguyen, L.H.; Song, M.Y.; He, X.S.; Fuchs, C.S.; Ogino, S.; Willett, W.C.; et al. Association of obesity with risk of early-onset colorectal cancer among women. JAMA Oncol. 2019, 5, 37-44. [CrossRef] [PubMed]

116. Whitlock, K.; Gill, R.S.; Birch, D.W.; Karmali, S. The Association between Obesity and Colorectal Cancer. Gastroenterol. Res. Pract. 2012, 2012, 1-6. [CrossRef] [PubMed]

117. Martinez-Useros, J.; Garcia-Foncillas, J. Obesity and colorectal cancer: Molecular features of adipose tissue. J. Transl. Med. 2016, 14, 21. [CrossRef] [PubMed]

118. Campbell, P.T.; Newton, C.C.; Kitahara, C.M.; Patel, A.V.; Hartge, P.; Koshiol, J.; McGlynn, K.A.; Adami, H.O.; De Gonzalez, A.B.; Freeman, L.E.B.; et al. Body Size Indicators and Risk of Gallbladder Cancer: Pooled Analysis of Individual-Level Data from 19 Prospective Cohort Studies. Cancer Epidemiol. Biomark. Prev. 2017, 26, 597-606. [CrossRef] [PubMed]

119. Nemunaitis, J.M.; Brown-Glabeman, U.; Soares, H.; Belmonte, J.; Liem, B.; Nir, I.; Phuoc, V.; Gullapalli, R.R. Gallbladder cancer: Review of a rare orphan gastrointestinal cancer with a focus on populations of New Mexico. BMC Cancer 2018, 18, 665. [CrossRef] [PubMed]

120. Picon-Ruiz, M.; Morata-Tarifa, C.; Valle-Goffin, J.J.; Friedman, E.R.; Slingerland, J.M. Obesity and Adverse Breast Cancer Risk and Outcome: Mechanistic Insights and Strategies for Intervention. CA Cancer J. Clin. 2017, 67, 379-397. [CrossRef] [PubMed]

121. Ando, S.; Gelsomino, L.; Panza, S.; Giordano, C.; Bonofiglio, D.; Barone, I.; Catalano, S. Obesity, leptin and breast cancer: Epidemiological evidence and proposed mechanisms. Cancers 2019, 11, 62. [CrossRef]

122. Neuhouser, M.L.; Aragaki, A.K.; Prentice, R.L.; Manson, J.E.; Chlebowski, R.; Carty, C.L.; Ochs-Balcom, H.M.; Thomson, C.A.; Caan, B.J.; Tinker, L.F.; et al. Overweight, obesity, and postmenopausal invasive breast cancer risk. A secondary analysis of the Women's Health Initiative randomized clinical trials. JAMA Oncol. 2015, 1, 611-621. [CrossRef]

123. Agurs-Collins, T.; Ross, S.A.; Dunn, B.K. The many faces of obesity and its influence on breast cancer risk. Front. Oncol. 2019, 9, 765. [CrossRef]

124. Beral, V.; Hermon, C.; Peto, R.; Reeves, G.; Brinton, L.; Marchbanks, P.; Negri, E.; Ness, R.; Peeters, P.H.M.; Vessey, M.; et al. Ovarian cancer and body size: Individual participant meta-analysis including 25,157 women with ovarian cancer from 47 epidemiological studies. PLoS Med. 2012, 9, e1001200. [CrossRef]

125. Kitahara, C.M.; McCullough, M.L.; Franceschi, S.; Rinaldi, S.; Wolk, A.; Neta, G.; Adami, H.O.; Anderson, K.; Andreotti, G.; Freeman, L.E.B.; et al. Anthropometric factors and thyroid cancer risk by histological subtype: Pooled analysis of 22 prospective studies. Thyroid 2016, 26, 306-318. [CrossRef] [PubMed] 
126. Zhao, S.T.; Jia, X.M.; Fan, X.J.; Zhao, L.; Pang, P.; Wang, Y.J.; Luo, Y.K.; Wang, F.L.; Yang, G.Q.; Wang, X.L.; et al. Association of obesity with the clinicopathological features of thyroid cancer in a large, operative population A retrospective case-control study. Medicine 2019, 98, e18213. [CrossRef] [PubMed]

127. Schmid, D.; Ricci, C.; Behrens, G.; Leitzmann, M.F. Adiposity and risk of thyroid cancer: A systematic review and meta-analysis. Obes. Rev. 2015, 16, 1042-1054. [CrossRef] [PubMed]

128. Dirat, B.; Bochet, L.; Dabek, M.; Daviaud, D.; Dauvillier, S.; Majed, B.; Wang, Y.Y.; Meulle, A.; Salles, B.; Le Gonidec, S.; et al. Cancer-associated adipocytes exhibit an activated phenotype and contribute to breast cancer invasion. Cancer Res. 2011, 71, 2455-2465. [CrossRef] [PubMed]

129. Dirat, B.; Bochet, L.; Dabek, M.; Daviaud, D.; Dauvillier, S.; Le Gonidec, S.; Escourrou, G.; Valet, P.; Muller, C. Cancer-associated adipocytes exhibit an activated phenotype and contribute to early breast cancer invasion in vitro and in vivo. EJC Suppl. 2010, 8, 126. [CrossRef]

130. Rybinska, I.; Agresti, R.; Trapani, A.; Tagliabue, E.; Triulzi, T. Adipocytes in breast cancer, the thick and the thin. Cells 2020, 9, 560. [CrossRef]

131. Bochet, L.; Lehuede, C.; Dauvillier, S.; Wang, Y.Y.; Dirat, B.; Laurent, V.; Dray, C.; Guiet, R.; Maridonneau-Parini, I.; Le Gonidec, S.; et al. Adipocyte-derived fibroblasts promote tumor progression and contribute to the desmoplastic reaction in breast cancer. Cancer Res. 2013, 73, 5657-5668. [CrossRef]

132. Cirri, P.; Chiarugi, P. Cancer associated fibroblasts: The dark side of the coin. Am. J. Cancer Res. 2011, 1, 482-497.

133. Nieman, K.M.; Romero, I.L.; Van Houten, B.; Lengyel, E. Adipose tissue and adipocytes support tumorigenesis and metastasis. BBA. Mol. Cell Biol. Lipids 2013, 1831, 1533-1541. [CrossRef]

134. Iyengar, N.M.; Hudis, C.A.; Dannenberg, A.J. Obesity and Cancer: Local and Systemic Mechanisms. Annu. Rev. Med. 2015, 66, 297-309. [CrossRef]

135. Wauman, J.; Tavernier, J. Leptin receptor signaling: Pathways to leptin resistance. Front. Biosci. 2011, 16, 2771-2793. [CrossRef] [PubMed]

136. Bowers, L.W.; Gung, J.; Lineberger, C.G.; Hursting, S.D. Abstract SY28-04: Obesity-associated leptin signaling promotes chemotherapy resistance in triple-negative breast cancer: The role of tumor-initiating cell enrichment. Tumor Biol. 2019. [CrossRef]

137. Sanchez-Jimenez, F.; Perez-Perez, A.; De la Cruz-Merino, L.; Sanchez-Margalet, V. Obesity and breast cancer: Role of leptin. Front. Oncol. 2019, 9, 596. [CrossRef]

138. Nowak, A.; Kobierzycki, C.; Dziegiel, P. The role of leptin in pathogenesis of obesity-related cancers. Postepy Biol. Komorki 2015, 42, 309-328.

139. Park, J.; Morley, T.S.; Kim, M.; Clegg, D.J.; Scherer, P.E. Obesity and cancer-mechanisms underlying tumour progression and recurrence. Nat. Rev. Endocrinol. 2014, 10, 455-465. [CrossRef]

140. Divella, R.; De Luca, R.; Abbate, I.; Naglieri, E.; Daniele, A. Obesity and cancer: The role of adipose tissue and adipo-cytokines-induced chronic inflammation. J. Cancer 2016, 7, 2346-2359. [CrossRef]

141. Booth, A.; Magnuson, A.; Fouts, J.; Foster, M. Adipose tissue, obesity and adipokines: Role in cancer promotion. Horm. Mol. Biol. Clin. Investig. 2015, 21, 57-74. [CrossRef]

142. Tumminia, A.; Vinciguerra, F.; Parisi, M.; Graziano, M.; Sciacca, L.; Baratta, R.; Frittitta, L. Adipose tissue, obesity and adiponectin: Role in endocrine cancer risk. Int. J. Mol. Sci. 2019, 20, 2863. [CrossRef]

143. Aronis, K.N.; Siatis, K.E.; Giannopoulou, E.; Kalofonos, H.P. Adiponectin promotes autophagy and apoptosis in endometrial cancer cell lines. Clin. Oncol. 2019, 4, 1-5.

144. Zhang, L.Z.; Wen, K.; Han, X.X.; Liu, R.; Qu, Q.X. Adiponectin mediates antiproliferative and apoptotic responses in endometrial carcinoma by the AdipoRs/AMPK pathway. Gynecol. Oncol. 2015, 137, 311-320. [CrossRef]

145. Jiang, J.H.; Fan, Y.C.; Zhang, W.; Sheng, Y.L.; Liu, T.T.; Yao, M.; Gu, J.R.; Tu, H.; Gan, Y. Adiponectin suppresses human pancreatic cancer growth through attenuating the beta-catenin signaling pathway. Int. J. Biol. Sci. 2019, 15, 253-264. [CrossRef] [PubMed]

146. Grossmann, M.E.; Cleary, M.P. The balance between leptin and adiponectin in the control of carcinogenesis -focus on mammary tumorigenesis. Biochimie 2012, 94, 2164-2171. [CrossRef]

147. Pollak, M. Insulin and insulin-like growth factor signalling in neoplasia. Nat. Rev. Cancer. 2008, 8, 915-928. [CrossRef] [PubMed] 
148. D’Esposito, V.; Passaretti, F.; Hammarstedt, A.; Liguoro, D.; Terracciano, D.; Molea, G.; Canta, L.; Miele, C.; Smith, U.; Beguinot, F.; et al. Adipocyte-released insulin-like growth factor-1 is regulated by glucose and fatty acids and controls breast cancer cell growth in vitro. Diabetologia 2012, 55, 2811-2822. [CrossRef]

149. Louie, S.M.; Roberts, L.S.; Nomura, D.K. Mechanisms linking obesity and cancer. BBA. Mol. Cell Biol. Lipids 2013, 1831, 1499-1508. [CrossRef] [PubMed]

150. Li, Z.; Zhang, C.; Du, J.X.; Zhao, J.; Shi, M.T.; Jin, M.W.; Liu, H. Adipocytes promote tumor progression and induce PD-L1 expression via TNF-alpha/IL-6 signaling. Cancer Cell Int. 2020, 20, 179. [CrossRef] [PubMed]

151. Duong, M.N.; Geneste, A.; Fallone, F.; Li, X.; Dumontet, C.; Muller, C. The fat and the bad: Mature adipocytes, key actors in tumor progression and resistance. Oncotarget 2017, 8, 57622-57641. [CrossRef]

152. Bolsoni-Lopes, A.; Alonso-Vale, M.I.C. Lipolysis and lipases in white adipose tissue-An update. Arch. Endocrinol. Metab. 2015, 59, 335-342. [CrossRef]

153. Ma, Y.B.; Temkin, S.M.; Hawkridge, A.M.; Guo, C.Q.; Wang, W.; Wang, X.Y.; Fan, X.J. Fatty acid oxidation: An emerging facet of metabolic transformation in cancer. Cancer Lett. 2018, 435, 92-100. [CrossRef]

154. Balaban, S.; Shearer, R.F.; Lee, L.S.; Van Geldermalsen, M.; Schreuder, M.; Shtein, H.C.; Cairns, R.; Thomas, K.C.; Fazakerley, D.J.; Grewal, T.; et al. Adipocyte lipolysis links obesity to breast cancer growth: Adipocyte-derived fatty acids drive breast cancer cell proliferation and migration. Cancer Metab. 2017, 5, 1. [CrossRef]

155. Zeng, J.; Sauter, E.R.; Li, B. FABP4: A New Player in Obesity-Associated Breast Cancer. Trends Mol. Med. 2020, 26, 437-440. [CrossRef]

156. Clement, E.; Lazar, I.; Attane, C.; Carrie, L.; Dauvillier, S.; Ducoux-Petit, M.; Esteve, D.; Menneteau, T.; Moutahir, M.; Le Gonidec, S.; et al. Adipocyte extracellular vesicles carry enzymes and fatty acids that stimulate mitochondrial metabolism and remodeling in tumor cells. EMBO J. 2020, 39, e102525. [CrossRef] [PubMed]

157. Lazar, I.; Clement, E.; Dauvillier, S.; Milhas, D.; Ducoux-Petit, M.; Le Gonidec, S.; Moro, C.; Soldan, V.; Dalle, S.; Balor, S.; et al. Adipocyte exosomes promote melanoma aggressiveness through fatty acid oxidation: A novel mechanism linking obesity and cancer. Cancer Res. 2016, 76, 4051-4057. [CrossRef] [PubMed]

158. Wang, S.H.; Xu, M.Q.; Li, X.X.; Su, X.D.; Xiao, X.; Keating, A.; Zhao, R.C. Exosomes released by hepatocarcinoma cells endow adipocytes with tumor-promoting properties. J. Hematol. Oncol. 2018, 11, 82. [CrossRef] [PubMed]

159. Park, J.; Euhus, D.M.; Scherer, P.E. Paracrine and Endocrine Effects of adipose tissue on cancer development and progression. Endocr. Rev. 2011, 32, 550-570. [CrossRef] [PubMed]

160. Castillo, J.J.; Mulkey, F.; Geyer, S.; Kolitz, J.E.; Blum, W.; Powell, B.L.; George, S.L.; Larson, R.A.; Stone, R.M. Relationship between obesity and clinical outcome in adults with acute myeloid leukemia: A pooled analysis from four CALGB (alliance) clinical trials. Am. J. Hematol. 2016, 91, 199-204. [CrossRef]

161. Cascetta, P.; Cavaliere, A.; Piro, G.; Torroni, L.; Santoro, R.; Tortora, G.; Melisi, D.; Carbone, C. Pancreatic cancer and obesity: Molecular mechanisms of cell transformation and chemoresistance. Int. J. Mol. Sci. 2018, 19, 3331. [CrossRef]

162. Mentoor, I.; Engelbrecht, A.M.; Nell, T. Fatty acids: Adiposity and breast cancer chemotherapy, a bad synergy? Prostaglandins Leukot. Essent. Fatty Acids 2019, 140, 18-33. [CrossRef]

163. Kounakis, K.; Chaniotakis, M.; Markaki, M.; Tavernarakis, N. Emerging roles of lipophagy in health and disease. Front. Cell Dev. Biol. 2019, 7, 185. [CrossRef]

164. Longo, V.D.; Fontana, L. Calorie restriction and cancer prevention: Metabolic and molecular mechanisms. Trends Pharmacol. Sci. 2010, 31, 89-98. [CrossRef]

165. Caccialanza, R.; Aprile, G.; Cereda, E.; Pedrazzoli, P. Fasting in oncology: A word of caution. Nat. Rev. Cancer 2019, 19, 177. [CrossRef] [PubMed]

166. Agostoni, C.; Bresson, J.L.; Fairweather-Tait, S.; Flynn, A.; Golly, I.; Korhonen, H.; Lagiou, P.; Lovik, M.; Marchelli, R.; Martin, A.; et al. Scientific Opinion on Dietary Reference Values for fats, including saturated fatty acids, polyunsaturated fatty acids, monounsaturated fatty acids, trans fatty acids, and cholesterol. EFSA J. 2010, 8, 1461. [CrossRef]

167. Stensrud, M.J.; Valberg, M. Inequality in genetic cancer risk suggests bad genes rather than bad luck. Nat. Commun. 2017, 8, 1165. [CrossRef]

168. Tomasetti, C.; Vogelstein, B. Cancer risk: Role of environment-Response. Science 2015, 347, $729-731$. [CrossRef] [PubMed] 
169. Thomas, F.; Roche, B.; Ujvari, B. Intrinsic versus extrinsic cancer risks: The debate continues. Trends Cancer 2016, 2, 68-69. [CrossRef]

170. Couzin-Frankel, J. The bad luck of cancer. Science 2015, 347, 12. [CrossRef] [PubMed]

171. Erazo-Oliveras, A.; Fuentes, N.R.; Wright, R.C.; Chapkin, R.S. Functional link between plasma membrane spatiotemporal dynamics, cancer biology, and dietary membrane-altering agents. Cancer Metastasis Rev. 2018, 37, 519-544. [CrossRef]

172. Chapkin, R.S.; DeClercq, V.; Kim, E.; Fuentes, N.R.; Fan, Y.Y. Mechanisms by Which Pleiotropic Amphiphilic n-3 PUFA Reduce Colon Cancer Risk. Curr. Colorectal Cancer Rep. 2014, 10, 442-452. [CrossRef]

173. Nicolson, G.L.; Ash, M.E. Lipid Replacement Therapy: A natural medicine approach to replacing damaged lipids in cellular membranes and organelles and restoring function. BBA Biomembr. 2014, 1838, 1657-1679. [CrossRef]

174. Peláez, R.; Pariente, A.; Pérez-Sala, Á.; Larráyoz, I.M. Sterculic Acid: The Mechanisms of Action beyond Stearoyl-CoA Desaturase Inhibition and Therapeutic Opportunities in Human Diseases. Cells 2020, 9, 140. [CrossRef]

175. Kim, K.B.; Nam, Y.A.; Kim, H.S.; Hayes, A.W.; Lee, B.M. $\alpha$-Linolenic acid: Nutraceutical, pharmacological and toxicological evaluation. Food Chem. Toxicol. 2014, 70, 163-178. [CrossRef] [PubMed]

176. Lien, E.C.; Vander Heiden, M.G. A framework for examining how diet impacts tumour metabolism. Nat. Rev. Cancer 2019, 19, 651-661. [CrossRef] [PubMed]

177. Kenny, F.S.; Pinder, S.E.; Elis, I.O.; Gee, J.M.W.; Nicholson, R.I.; Bryce, R.P.; Robertson, J.F.R. Gamma linolenic acid with tamoxifen as primary therapy in breast cancer. Int. J. Cancer 2000, 85, 643-648. [CrossRef]

(C) 2020 by the authors. Licensee MDPI, Basel, Switzerland. This article is an open access article distributed under the terms and conditions of the Creative Commons Attribution (CC BY) license (http://creativecommons.org/licenses/by/4.0/). 